\title{
Profiling causative factors leading to construction project delays in the United Arab Emirates
}

Bekithemba Mpofu, Edward Godfrey Ochieng, Cletus Moobela, Adriaan Pretorius

\section{Abstract}

The timely delivery of projects is one of the most important needs of clients in the construction industry and yet it still remains a highly challenging undertaking the world over. From the reviewed literature, it has been suggested that such delays usually come with and lead to far reaching consequences in the form of adversarial relationships, mistrust, litigation, arbitration, cash-flow problems, and a general feeling of trepidation towards stakeholders within the construction industry. A voluminous amount of research has been conducted on this problem in the recent past however, the persistence of the problem demands that a relentless quest for solutions is upheld. It can be argued that the problem is likely to be more pronounced in areas where development pressure is the highest. One such area is the United Arab Emirates (UAE) where the construction industry is said to have reached an unparalleled position in the last decade. Moreover, the problems of construction delays may differ from one region to another due to numerous differentiating factors. This study sought to identify the most significant causes of delays in the UAE construction industry. A survey was conducted, targeting three key types of stakeholders, namely clients, contractors and consultants. From the analysis, the study unveiled a number of important causes of construction delays in the UAE, ranging from unrealistic contract durations to poor labour productivity, with consultants and clients seemingly shouldering the bulk of the 'blame game'.

Keywords: United Arab Emirates, Construction delay, Construction industry, Construction practitioners, Project management.

\section{Introduction}

Delivery of projects in a timely manner is one of the most important needs of clients of the construction industry. However, it still remains a highly challenging undertaking in many countries across the globe (Flyvberg, 2014; Ochieng et al., 2013a). Such delays usually come with and lead to far reaching consequences in the form of adversarial relationships, mistrust, litigation, arbitration, cash-flow problems, and a general feeling of trepidation towards other stakeholders (Ahmed et al., 2003). Previous efforts have yielded very little and this is evident in the persistence of the problem. It can be argued that the problem is likely to be more pronounced in areas where development pressure is the highest, such as the United Arab Emirates (UAE) where the construction sector is said to have reached an unparalleled position in the last decade. Moreover, the problems of construction delays may differ from one region to another due to numerous social, economic, and cultural factors. The United Arab Emirates (UAE) construction industry has reached 
an unparalleled position in the last decade (BMI, 2013). Considering the high contribution to overall economy and development the construction industry is an important sector in the UAE (BMI, 2013). Thus, it is important to identify the most significant causes of delay in the UAE construction industry to be able to find ways to avoid them, or at least, mitigate their impact. According to Business Monitor International (BMI, 2013), the UAE's construction industry value was forecasted at approximately $\$ 41 \mathrm{bn}$ in 2013 , representing a real value annual growth of 4.5 per cent. In Dubai alone, the property and construction sector contributed 21 per cent of the Emirate's GDP growth in the first half of 2013 - putting it second only to the retail and wholesale sector.

It is worth noting that any construction project comprises two distinct phases: the preconstruction phase (the period between the initial conceptions of the project to awarding of the contract) and the construction phase (period from awarding the contract to when the actual construction is completed). Delays occur in both phases, however the major instances of project delays usually take place in the construction phase (Frimpong et al., 2003). This has led to the need to identify exactly the relevant causes of time delay, with particular emphasis on the construction phase. Practitioners need to develop the capacity to foresee potential problems likely to confront their current and future projects. Identification of the common problems experienced on past projects in their construction business environment is a good option (Long et al., 2004). Unfortunately, due to various reasons, project successes are not common in the construction industry. Groak (1994) stated that construction is not a single entity, as there are several industries overlapping its activities. As suggested by Groak (1994), it is crucial to understand that many 'problems' of construction are not problems to be eliminated from our work or anomalies to be excluded from our theoretical models. They are characteristics, which emerge depending on the projects and which we should recognise as necessary components of our analytical methods. What we now term 'the industry paradigm', has also defined the parameters of change in discussions of how we improve both the performance and products of this industry. Groak (1994) identified real issues within the construction industry namely:

- Buildability - This is limited by its implication that contracting organisations are interchangeable. It does not sufficiently acknowledge that there are great variations in the skills and resources between organisations;

- Fragmentation - The separation of design and production skills or other forms of the divisions of labour, including subcontracting, are seen as particular problems for construction. This implies that some form of regularly coordinated or unified organisations must be preferable to one which is assembled for a specific project;

- Feedback - In construction we know remarkably little about feedback. Whether feedback is during the design and construction process or is from the construction in use. 
It is worth mentioning that, in 2006, Faridi et al. identified ten major causes of construction delay in UAE. One major criticism of Faridi et al.'s (2006) work is that data was drawn from two set of construction practitioners (contractors and consultants). The present study had three types of respondents 'contractors, consultants and clients. In addition, there have been few studies aimed at exploring construction delay factors in UAE. In the light of these issues, the aim of this research was therefore to identify the most significant causes of delays in the UAE construction industry and propose solutions. The next section presents a review of construction delays. This is followed by an explanation of the method used, findings and discussion.

\section{Appraisal of construction delays}

A successful construction project is said to be one that has accomplished its technical performance, maintained its schedule and remained within budgetary provision (Frimpong et al., 2003). Delays are usually accompanied by cost overruns. These have a debilitating effect in terms of adversarial relationships, mistrust, litigation, arbitration, cash-flow problems, and a general feeling of trepidation towards other stakeholders (Ahmed et al., 2003). The Latham Report (Latham, 1994) suggested that ensuring timely delivery of projects is one of the important needs of clients of the construction industry. According to Ahmed et al. (2003) delays on construction projects are a universal phenomenon. When projects are delayed, they are either extended or accelerated and therefore, incur additional cost. To the client, delay means loss of revenue through non availability of production facilities and rentable space or a dependence on present facilities. In some cases, delay causes higher overhead costs to the contractor because of longer work period, higher material costs through inflation, and due to labour cost increases. Completing projects on time is an indicator of efficiency, but the construction process is subject to many variables and unpredictable factors, which result from many sources (Assaf and Al-Hejji, 2006). Love et al. (2013) suggested that two different viewpoints exist with regard to cost overrun. According to Love et al. (2013), within the infrastructure and transport literature, cost overruns are invariably calculated from the decision to build. In contrast, within the construction and engineering management literature, cost overruns are determined from contract award.

Much emphasis is now placed on projects to be completed within the specified project duration due to current trend of shifting most projects towards the fast track approach (Faridi and El-Sayegh, 2006). Hence, realistic construction time has become increasingly important because it often serves as a crucial benchmark for assessing the performance of a project and the efficiency of the contractor (Chan and Kumaraswamy, 2002). The causes and effects of delay factors in construction industry vary from country to country due to environmental, topographical and technological constraints (Shebob et al., 2012). In anticipation of the effect of globalization and the technological difference between developing and developed countries, it is was essential to identify the actual reasons of delay in order to reduce the impact of delay in any construction project. From 
the reviewed literature, the researchers were able to identify a total of 180 factors influencing construction project delivery time either positively or negatively. These were grouped into eleven groups (see Table 5) and consolidated into eight groups as depicted by Table 6-13, corresponding to the four key stakeholders: clients; contractors; consultants; and the labour-force.

\subsection{Factors related to clients}

Belout and Gauvreau (2004) pointed out that it is important to define and communicate the project mission clearly during the planning stage. Further, it is also essential at this stage to fully grasp clients' needs and establish with them the project's limits and priorities. Chan et al. (2004) identified that the accuracy of the briefing to the design team regarding the intention of the project is directly proportional to the level of design. Inappropriately conveyed intentions are most likely to affect the design. The ability of the client to effectively and unequivocally brief the design team could avoid revision of drawings and reworks while a client's indecisiveness and non-uniformity can negatively affect project delivery (Phua, 2005; Faridi and El-Sayegh, 2006; Blismas et al., 2004). The extent to which the client can make authoritative decisions helps in avoiding delays in the delivery of projects. Clients that need to consult other associates with respect to making decisions may affect prompt delivery of projects. In addition stability of decisions is very crucial in the construction process.

It is worth noting that, changes in decisions may lead to changes in design, rework, and resource wastage thereby leading to project delays (Abdel-Wahab et al., 2008). A more complex situation is often triggered when a number of changes or variations are ordered by the client. The cumulative (synergistic) impacts of multiple changes are particularly troublesome to resolve (Hester et al., 1991). A fundamental duty of the client is to provide the contractor with the project site. A client may interfere with the contractor's access to the site and fail to cooperate by, for example, denying access to the project, imposing restricted work areas, using the site in a way that impedes the contractor's work at the site, or allowing other contractors to work on the project site in a way that interferes with the contractor's work. Another key factor associated with clients relates to delays in progressing payments. The hierarchical structure of the construction industry supply chain means that payments tend to flow from the client to the main contractor, who then pays the project's subcontractors, who in turn pay their own sub-contractors. This can easily translate into cash flow problems to these entities.

\subsection{Factors related to design consultants}

Problems with design and planning are a major cause of change orders which can lead to delays in the delivery of projects (Hsieh et al., 2004). Research indicates that poor design management contributes to project performance (Fugar and Agyakwah-Baah, 2010; Santoso et al., 2003). There is generally an accepted view that to minimise claims, more time and money should be allocated to 
a project's design phase in order to reduce the number of changes to the contract (Zack, 1997). However, even if such suggestions are possible to implement, which is not always so in practice, the nature of construction is such that changes to the work are to be expected no matter how much effort is expended at the design stage. Changes are inevitable due to the high level of uncertainties within construction projects and the inability of designers to provide for all possible eventualities (Laufer et al., 1992). As illustrated in Figure 1, in the initial stages of a project, when the amount of money spent on the project is still at its lowest, the possibility of influencing the design and the direction of the project is at its highest (Gould and Joyce, 2009).

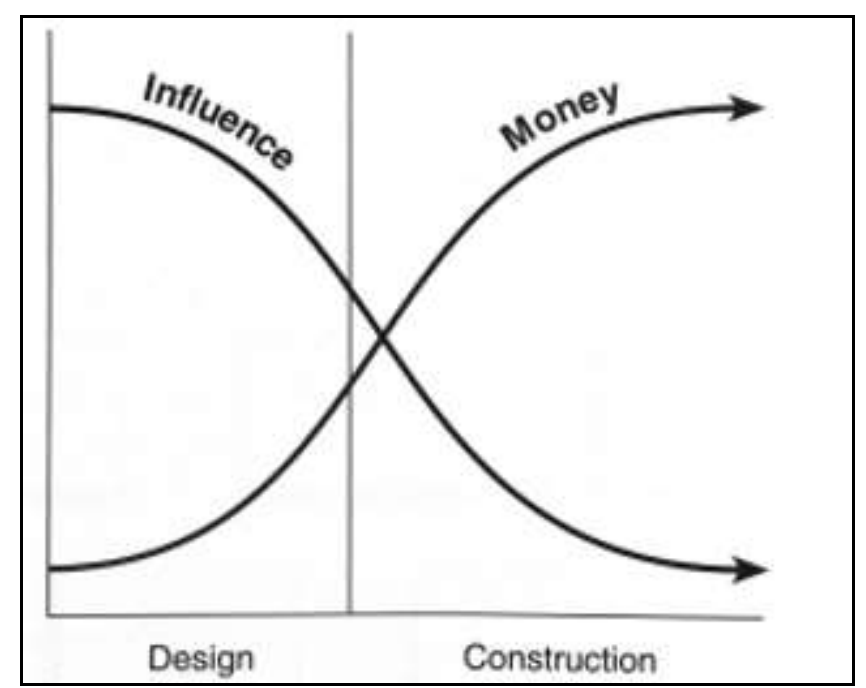

Figure 1: Project influence of expenditure

Source: Gould and Joyce, 2009

The ability to influence the project decreases with time while the amount of money spent increases. Once the project has been initiated and the construction phase started, any changes made can be costly both in time and monetary expenditure. Similarly, design changes have been found to be the most significant source of construction wastage (Faniran et al., 1994). Ambiguous specifications can negatively affect project delivery time (Acharya et al., 2006). That is why it is advisable that designs are reviewed by the contractor for clarity and to avoid ambiguity upon receiving the award to avoid delays (Oyedele and Tham, 2006). According to Walker and Shen (2002), delays in design documentation can also negatively affect project delivery. Time should not be wasted in the process of issuing revised drawings and revisions of designs should be done promptly. This is also supported by Andi and Minato (2003) who argued that poor design and documentation quality negatively affect the construction process, while Al-Aghbari (2005) associate incomplete documents as one of the top ten factors causing delay in the delivery of projects in the Malaysian construction industry. 


\subsection{Factors related to contractors}

Inadequate supervision of work, increased project costs, and abandonment can result in rework. Sambasivan and Soon (2007) suggested that poor site management on the part of the contractor ranks among the ten most common influencing factors causing delays on project delivery. Planning helps minimise the travelling time and movement costs of plant, labour and materials, activity interference during construction work and site accidents (Tam et al., 2002). However, a number of researchers and commentators have decried that most contractor programmes are often poorly prepared and not properly updated to reflect changes that occurred during the course of the project (Winter and Johnson, 2000; Kazaz and Ulubeyli, 2003; Chan et al., 2004). Such deficiencies in programming practices make it difficult for analysts to measure accurately the effect of various delay events on project completion.

Other contractor related factors include those associated with materials and plant and machinery availability. Lack of strategic planning for materials has been identified as a major cause of delays in project delivery (Al-Kharashi and Skitmore, 2008; Dai et al., 2007). Pongpeng and Liston (2003) point out that plant and equipment availability are criteria accredited for contractors' performance measurement. Inadequate supply or lack of tools and equipment contribute adversely to project delivery. Some of the issues relating to equipment and tools that influence productivity are lack of proper tools and equipment, insufficient tools and equipment, ignoring maintenance programmes, a shortage of spare parts and ignoring the capacity of equipment. Additionally, O'Connor and Yang (2004) suggested that the construction industry has been criticised for its slow adoption of emerging technologies and conclude that higher levels of project schedule success are particularly associated with high level of technology utilisation.

\subsection{Labour related issues}

Absenteeism can create enormous problems for the construction industry, thereby seriously affecting planning by reducing the effectiveness of teamwork and output, and causing plant and machinery to stand idle (Lim and Ling, 2002). Contractors are often involved in tight schedules, resulting in a need to accelerate construction programmes and increase working hours. Excessive overtime has been found to be counter-productive (Proverbs and Holt, 2000). Work schedules that extend beyond 40 hours per week reduce labour productivity, without material benefit to the completion schedule (Business Round Table, 1991). Therefore, the use of excessive overtime to combat time restraints inhibits long-term improvements in performance. According to Flanagan et al. (1986), the average construction worker is only productive for 40 per cent of the time; the remaining 60 per cent is spent on moving from one task to another or waiting for materials and/or instruction. Productivity can be impaired by numerous factors including: poor management and supervision; disruptions to work; inclement weather conditions; frequent changes in specifications; inefficient construction methods; and over-manning. The fragmented structure of the industry also 
contributes towards the productivity conundrum (Cox and Townsend, 1997). The factors of motivation that can influence workers' attitudes either negatively or positively regarding productivity include pay and allowances, job security, a sense of belonging and identification with the project team, recognition of contribution, opportunity for extending skills and experience through learning, equitable reward, exercise of power, and opportunities for career advancement (Cox and Townsend, 1997).

\section{Other construction delay issues}

From the reviewed literature, other construction delay issues were identified. These were classified into four categories:

\subsection{Fragmentation}

The construction industry has always suffered from fragmentation owing to the temporary nature of project execution and the various technical, financial and managerial specialisms that are incorporated into a project (Sullivan and Harris, 1985). Fragmentation of the construction industry inhibits performance. The effects of fragmentation can be reduced through integrated working (Ochieng and Price, 2010). Integrated working not only improves value for the client, but also allows time for firms in the supply chain to develop business relationships with each other, creating an environment that encourages investment in capacity and innovation. Despite the potential benefits for all involved, progress in adopting integrated working has been slow (Ochieng and Price, 2009; Ochieng et al., 2013b).

\subsection{Buildability}

Buildability represents the extent to which the design of a building facilitates ease of construction, subject to the overall requirements for the completed building. Thus, construction productivity, which is a measure of efficiency and effectiveness of a contractor's resources employed can be affected by the buildability performance of designs (Oglesby, 1989). In fact, low productivity has been attributed to the insufficient attention being paid to buildable design (CIDB, 1992). Under the traditional method, contractors do not have any involvement in developing the design on which they base their work. This practice has been one of the major hurdles hindering the improvement of buildability (Wong et al., 2006). On the other hand, comparatively few projects adopt nontraditional procurement methods, such as management contracting or construction management, to which a contractor can contribute its construction expertise (Tam et al., 2004).

Problems of buildability stem from a number of sources (Wong et al., 2006). At the project level, these problems are due to designers' lack of knowledge and experience in construction; designing without input or the involvement of contractors; projects with increasingly demanding coordination requirements (such as sophisticated building services and building automation systems); an 
ignorance of contractors' proposed changes, a lack of communication between the parties involved, etc. Added to these, the tight timeframe for designing has also resulted in designers not having enough time to prepare careful designs. The highly fragmented roles and specialisation of various consultants in a project team further complicate the responsibility for effecting buildability improvements. Potential benefits of improved buildability are multi-faceted. Numerous studies across the world have pointed to the tangible benefits of time, cost, quality, and safety, as well as intangible benefits brought about by improved buildability (see Table 1). Apart from these potential gains, buildable designs can also bring about increased productivity. To this end, as building designs have significant effects on downstream activities, design professionals should no longer indulge themselves in aesthetic excellence, but take a lead to enhancing buildability (Smith, 1999).

Table 1: Benefits associated with improved buildability

\begin{tabular}{|c|c|c|}
\hline \multicolumn{2}{|c|}{ Benefits of improved buildability } & \multirow{2}{*}{$\begin{array}{l}\text { References } \\
\text { Francis et al. (1999), Low and } \\
\text { Abeyegoonasekera (2001), Elgohary et al., } \\
\text { (2003) }\end{array}$} \\
\hline Time & Early completion of projects & \\
\hline Cost & $\begin{array}{l}\text { Safe project cost / achieved cost effectiveness for project/ } \\
\text { Reduce extra cost of change orders / Reduce cost of } \\
\text { construction bids }\end{array}$ & $\begin{array}{l}\text { Francis et al. (1999), Low and } \\
\text { Abeyegoonasekera (2001), Elgohary et al., } \\
\text { (2003) }\end{array}$ \\
\hline Quality & Improved quality performance of projects & $\begin{array}{l}\text { Francis et al. (1999), Low and } \\
\text { Abeyegoonasekera (2001), Elgohary et al } \\
\text { (2003), Trigunarsyah (2004) }\end{array}$ \\
\hline Safety & Improved safety performance of projects & $\begin{array}{l}\text { Francis et al. (1999), Low and } \\
\text { Abeyegoonasekera (2001), Trigunarsyah } \\
(2004)\end{array}$ \\
\hline Others & $\begin{array}{l}\text { Higher productivity levels / Reducing the risks of unforeseen } \\
\text { problems / Improved industrial relations / Better teamwork / } \\
\text { Improved communication / Enhanced client and customer } \\
\text { satisfaction / Better resource utilization and overhead savings / } \\
\text { Reduced project risks / Better working relationships }\end{array}$ & $\begin{array}{l}\text { Eldin (1999), Francis et al. (1999), Low } \\
\text { and Abeyegoonasekera (2001), Elgohary } \\
\text { et al (2003), Trigunarsyah (2004) }\end{array}$ \\
\hline
\end{tabular}

\subsection{Problems of finance}

A delayed payment by a party who is involved in the process of payment claim may have an influence on the supply chain of payments as a whole. Problems in payment at the higher end of the hierarchy will lead to a serious knock-on effect on cash flow problems down the chain. For example, in the case of Dawnays Ltd v F G Minter Ltd (1971), Lord Denning famously said that cash flow is the life-blood of the construction industry and ease of cash flow is an essential element in delivering a successful project (Speaight, 2010). The causes of poor cash flow management for contractors can be identified as: contractors handling too many projects at the same time; contractors' unstable financial backgrounds; unqualified contractors underbidding the project cost; lack of regular cash flow forecasting; poor credit arrangements with creditors and debtors; capital lockup; and difficulties in obtaining credit (Phua, 2005; Abdul-Rahman et al., 2006). Financial risk in the form of high interest rates can also negatively affect the performance of construction projects (Wiguna and Scott, 2005). A project may be delayed when the funds 
provided for the importation of a product are not sufficient to purchase the product as a result of an increase on interest rates or inflation because of the time it will take to source additional funding.

\subsection{Communication and information}

Phua (2005) contends that the factor that has the most influence on project success is communication between project firms and clients. This was supported by Assaf et al. (1995) whose study discovered that difficulty in coordination between the parties is one of the factors that contribute to delay. The factors identified in the literature review were collated and grouped into a framework of eleven categories as presented in Table 2.

Table 2: Summary of delay factors in construction projects

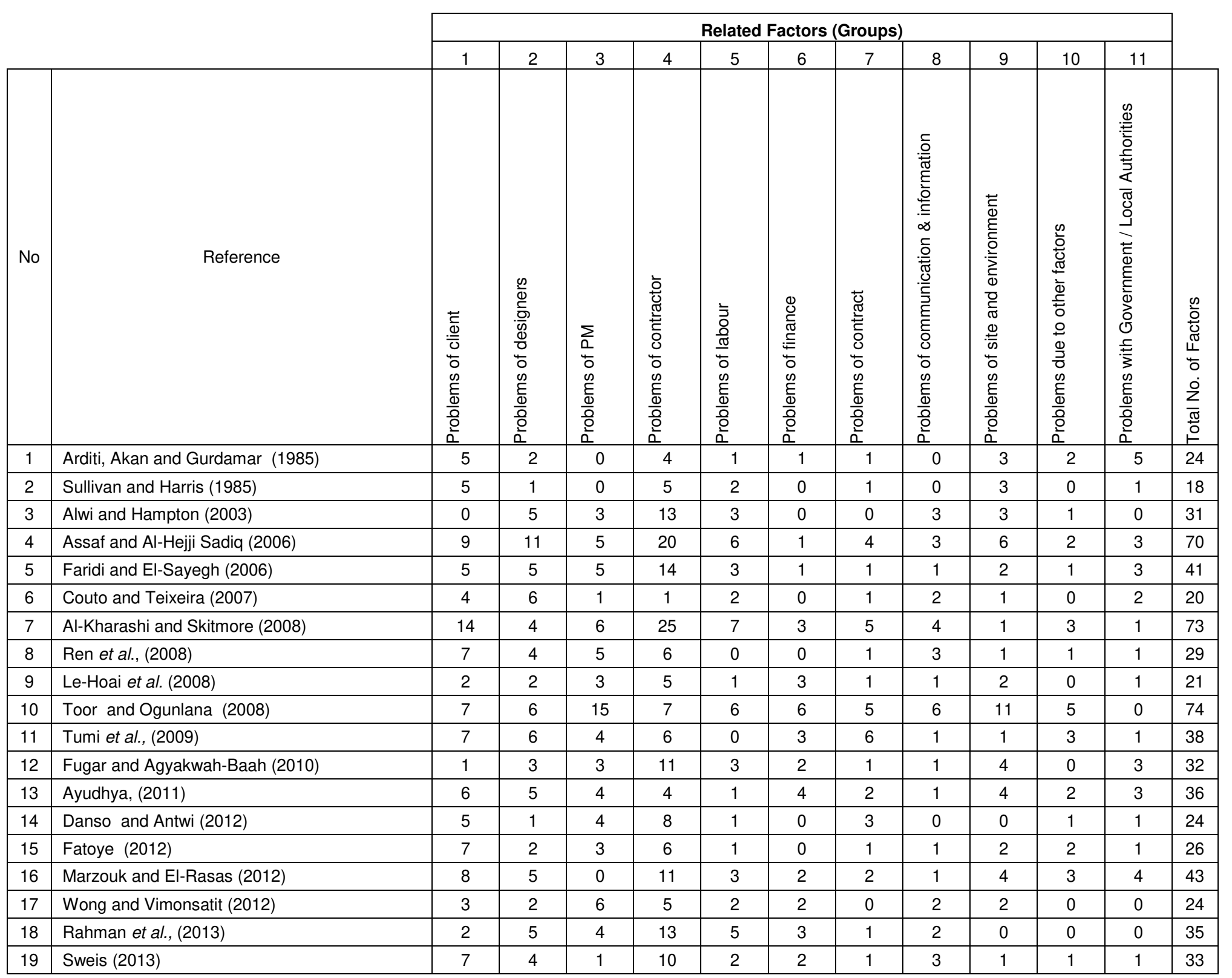


From the tabulation of factors causing delays in construction projects, it would appear that researchers focused on selected categories for study and analysis and that certain factors have been categorised under different groups by different researchers. This should be expected considering that the factors are likely to vary depending on specific regions. That is why it was felt necessary to conduct a UAE-focused study to determine those factors that are relevant to this region with a vibrant construction industry. The next section provides a description of the research method used in this study.

\section{Method}

There are different methods and approaches that have previously been adopted by various researchers on the subject of construction project delays as detailed in Table 3.

Table 3: Methods adopted for the analysis of construction project delays in other countries

\begin{tabular}{lll}
\hline Reference & Method of Analysis & Place studied \\
\hline Arditi et al., (1985) & Average Relative weights & Turkey \\
Sullivan and Harris (1985) & Frequency of Occurrence & UK \\
Alwi and Hampton (2003) & Importance Index & Indonesia \\
Assaf and Al-Hejji Sadiq (2005) & Importance Index & Saudi Arabia \\
Faridi and El-Sayegh (2006) & Relative Importance Index (RII) & Dubai (UAE) \\
Couto and Teixeira (2007) & Mean Value & Portugal \\
Al-Kharashi and Skitmore (2008) & ANOVA & Saudi Arabia \\
Le-Hoai et al. (2008) & Importance Index & Vietnam \\
Toor and Ogunlana (2008) & ANOVA & Thailand \\
Ren et al., (2008) & Severity weight method & Dubai (UAE) \\
Tumi et al., (2009) & Mean Value & Libya \\
Ayudhya (2011) & Severity Index & Singapore \\
Fugar and Agyakwah-Baah (2010) & Relative Importance Index (RII) & Ghana \\
Danso and Antwi (2012) & Relative Importance Index (RII) & Ghana \\
Fatoye (2012) & Relative Importance Index (RII) & Nigeria \\
Marzouk and El-Rasas (2012) & Importance Index & Egypt \\
Wong and Vimonsatit (2012) & Relative Importance Index (RII) & Australia \\
Rahman et al. (2013) & PLS-SEM & Malaysia \\
Sweis (2013) & Severity Index & Jordan \\
\hline
\end{tabular}

Each and every study has a different scope and obviously different conclusions. It would appear though that the concept of relative importance is common to most of the methodological approaches. For this study, the survey approach was selected as the most suitable method in an attempt to provide a holistic view of factors causing time overrun in the UAE construction industry. Surveys are efficient in that many variables can be measured without substantially increasing the time or cost. Survey data can be collected from many people at relatively low cost and, depending on the survey design, relatively quickly. Survey methods lend themselves to probability sampling from large populations (Loosemore et al., 1996). Thus, survey research is very appealing when sample generalizability is a central research goal. Surveys also are the method of choice when cross-population generalizability is a key concern because they allow a range of educational 
contexts and subgroups to be sampled. The consistency of relationships can then be examined across the various subgroups.

For this study primary data collection was conducted in three stages namely: narrow down factors as identified during the literature review, develop questionnaire design and conduct a pilot study and administer the questionnaire survey. During the literature review of earlier studies, a consolidated list of 180 factors around the world that cause time delays on construction projects were identified. Although this list is comprehensive, many of these factors are not consistent with the conditions and circumstances surrounding UAE. The study aimed to collect data from the three main stakeholders within the construction industry namely clients, consultants and contractors. A two stage piloting process was arranged: in the first stage of piloting, a draft copy of the questionnaire was given to six members academicians: one specialising in statistical analysis, another specialising in questionnaire design. They were four experienced academic staff who were knowledgeable in the field of project management. Feedback was received from each member of staff and modifications were subsequently made to the questionnaire. In the second stage of the piloting, the modified questionnaire was administered to thirty experienced senior construction practitioners at a workshop. The purpose of the pilot study was to assess clarity of questions, suitability of the respondents and ensure key construction delay variables were identified. After carrying out the piloting process, some changes were made to the draft questionnaire. No major substantive modifications were made, except for small alterations to question phrasing, sequencing, terminology, and some reduction to the questionnaire length. Given that the purpose of the research was to identify the most significant causes of delays in the UAE construction sector, there was an effort to make the questions, clear, brief, simple, and still meaningful in order to omit ambiguity.

As suggested by Gill and Johnson (2002), the validity and reliability of the data are also influenced by the design of the questionnaire. The design of the questionnaire was carried out with due attention to the areas of: questionnaire focus, questionnaire phraseology, question sequence and overall presentation. Gill and Johnson (2002) argued that in order to generalise from a simple random sample and avoid sampling errors or biases, the sample needs to be of an adequate size. What is adequate will depend on a number of issues, which often confuse people carrying out research for the first time. It is important that the absolute size of the sample is selected relative to the complexity of the population, the aims of the study and the kinds of statistical manipulation that will be used in data analysis and not the proportion of the sample selected relative to the complexity of the population. However, Sekaran (1992) argued that sample sizes larger than thirty and less than five hundred are appropriate for most research. Given the need for in-depth information, constraints of time and research approach, it seemed sensible to aim for a sample size towards the upper end of the size limit specified by Sekaran (1992). The size of sample was 
determined by the expected variation of findings from the three main stakeholders (clients, consultants and contractors). In choosing the sample size, the key aim was to achieve a balance between the level of representation required within the matrix represented by the maximum sample size, and the time constraints involved in obtaining data from the chosen respondents. Being able to define the target population and adopting the most appropriate sampling technique were also of great relevance as both factors reduce the likelihood of ambiguous conclusions. In the light of the above, information concerning construction organizations in the UAE was drawn from an annually published local building magazine which ranked top construction companies in the Gulf Cooperation Council (GCC). Other information from the magazine provided a list of clients, consultants, supplier groups and contractors but not all these were relevant for the study. Additional contacts were established using Linkedln and through snowballing. The sample frame consisted of about one hundred medium and large scale companies with various levels of fixed assets, qualified personnel and capital. The sample selection adopted was non-random sampling. The target sample in this study comprised of the leading construction companies in the UAE. This was deemed the most appropriate to achieve the research objective. The following criteria served as the primary basis for the final selection: size, experience, expertise and specialisation within the construction industry. It is important to state that in choosing the sample size, the key aim was to achieve a balance between the level of representation required within the matrix represented by the maximum sample size, and the time constraints involved in obtaining data from the chosen respondents.

In addition, there was a margin of error and confidence level which was considered. From a margin of error perspective, the deviation between the opinions of the respondents and the opinion of the entire population was considered. From a confidence level viewpoint, the sample was selected from the same population and each set of data was used to produce a different confidence interval. The confidence interval included the true population parameter. It is worth noting that, the population consisted of approximately 500 experienced stakeholders (clients, consultants and contractors). To ensure the appropriate number of completes was achieved, the margin of error was set at 5 per cent and confidence level at 95 per cent. As a consequence, the required sample size was set at approximately 218. The more varied the data was, the larger the sample size we needed to attain to ensure precision. Thus, a total of 500 questionnaires were distributed and 208 responses were received. This indicates a response rate of almost 42 per cent, which was positively influenced by the snowball sampling technique. To speed up the data collection process, the questionnaires were distributed to targeted groups via Survey Monkey, an online selfadministered questionnaire. According to Delamont et al. (1997), the use of snowball strategies provides a means of accessing vulnerable and more impenetrable social groupings. As shown in Table (4), the target groups for data collection included general managers, site project managers, quantity surveyors, cost consultants, planners, engineers and construction managers who had 
specific experiences in construction project delivery in UAE. It worth noting that, most of the participants had a long-standing familiarity in delivering medium, large and complex projects.

Table 4:Target group from United Arab Emirates

\begin{tabular}{|c|c|c|c|c|}
\hline Participants & Sector & $\begin{array}{c}\text { Projects involved } \\
\text { with }\end{array}$ & $\begin{array}{c}\text { Number of years } \\
\text { worked in the sector }\end{array}$ & $\begin{array}{c}\text { Years involved in } \\
\text { managing } \\
\text { construction projects } \\
\text { in UAE }\end{array}$ \\
\hline General managers & Construction & $\begin{array}{c}\text { Construction } \\
\text { projects }\end{array}$ & $\begin{array}{c}1-5 \text { years; } 11-15 \\
\text { years; } 16-20 \text { years }\end{array}$ & $\begin{array}{c}1-5 \text { years; } 11-15 \text { years; } \\
16-20 \text { years }\end{array}$ \\
\hline Site project managers & Construction & $\begin{array}{c}\text { Construction } \\
\text { projects }\end{array}$ & $\begin{array}{c}1-5 \text { years; } 11-15 \\
\text { years; } 16-20 \text { years }\end{array}$ & $\begin{array}{c}1-5 \text { years; } 11-15 \text { years; } \\
16-20 \text { years }\end{array}$ \\
\hline Quantity surveyors & Construction & $\begin{array}{c}\text { Construction } \\
\text { projects }\end{array}$ & $\begin{array}{c}1-5 \text { years; } 11-15 \\
\text { years; } 16-20 \text { years }\end{array}$ & $\begin{array}{c}1-5 \text { years; } 11-15 \text { years; } \\
16-20 \text { years }\end{array}$ \\
\hline Cost consultants & Construction & $\begin{array}{c}\text { Construction } \\
\text { projects }\end{array}$ & $\begin{array}{c}1-5 \text { years; } 11-15 \\
\text { years; } 16-20 \text { years }\end{array}$ & $\begin{array}{c}1-5 \text { years; } 11-15 \text { years; } \\
16-20 \text { years }\end{array}$ \\
\hline Planners & Construction & $\begin{array}{c}\text { Construction } \\
\text { projects }\end{array}$ & $\begin{array}{c}1-5 \text { years; } 11-15 \\
\text { years; } 16-20 \text { years }\end{array}$ & $\begin{array}{c}1-5 \text { years; } 11-15 \text { years; } \\
16-20 \text { years }\end{array}$ \\
\hline Engineers & Construction & $\begin{array}{c}\text { Construction } \\
\text { projects }\end{array}$ & $\begin{array}{c}1-5 \text { years; } 11-15 \\
\text { years; } 16-20 \text { years }\end{array}$ & $\begin{array}{c}1-5 \text { years; } 11-15 \text { years; } \\
16-20 \text { years }\end{array}$ \\
\hline Construction managers & Construction & $\begin{array}{c}\text { Construction } \\
\text { projects }\end{array}$ & $\begin{array}{c}1-5 \text { years; } 11-15 \\
\text { years; } 16-20 \text { years }\end{array}$ & $\begin{array}{c}1-5 \text { years; } 11-15 \text { years; } \\
16-20 \text { years }\end{array}$ \\
\hline
\end{tabular}

The questionnaire comprised of three parts: background information of respondent, general questions and industry causative project delays variables for the three main stakeholders. The sequence of questions was given consideration to develop a logical and sequential structure for the entire questionnaire. To achieve this, a funnel approach which comprised of less difficult questions to more complex ones was adopted. The first section of the questionnaire was used to obtain general information about the respondents. Respondents were asked to indicate their roles and level of work experience in the construction sector. In the second part of the questionnaire, respondents were asked to specify their socio-demographic characteristics; numbers of years worked in the sector and then identify a project they had completed in UAE. In the final part of the questionnaire, respondents were asked to designate the degree of severity for each cause/factor. As noted by Knight and Ruddock (2009), it is most essential to establish the framework for analysis before collecting any data, and in this respect, the degree of severity was categorized on a fivepoint Likert scale as follows: 1-Extremely significant (ES), 2-Very significant (VS), 3-Moderately significant (MS), 4-Slightly significant (SS), and 5-Not significant (NS). The Likert scale was based on a synthesis of potential delay causes and effects identified from past research. The essence of the five point categorisation was to elicit responses that indicated the relative significance of the severity of the identified delays causes/factors. A few other questions in other sections were constructed to gather facts, knowledge and the opinions of the respondents either in open-ended or close ended formats. The open ended questions enabled respondents to provide answers and views in their own words. Normally, these types of questions make the analysis and interpretation of data more cumbersome. On the other hand, closed questions entail predefining a set of possible responses. With just a few exceptions, the entire questionnaire adopted the use of closed 
questions because most concepts were well defined and potential responses were known based on the taxonomies drawn from the literature.

Several statistical methods were used to analyse the data collected from the questionnaires. The first one was the reliability test using Cronbach's alpha coefficient. The second one was Relative Importance Index (RII) to measure the level of importance of factors indicated by respondents. The Cronbach's alpha reliability test was carried out for testing the reliability of the 5-point Likert scale. This method assesses intrinsic consistency on the basis of the average correlation between data that were measured in an identical manner (Cronbach, 1951). Cronbach's alpha can be calculated as follows:

$$
\alpha=\frac{k}{k-1}\left(1-\frac{\sum \sigma_{i}^{2}}{\sigma_{i}^{2}}\right)
$$

Where: $k$ is the number of items, $\sigma_{i}^{2}$ variance of each item, $\sum \sigma_{i}^{2}$ is a total variance (Kline 1999).

The Cronbach's coefficient a test was carried out for testing the reliability of the 5-point Likert scale, for all variables under each category. These are shown in Table 5.

Table 5: Cronbach's coefficient $\alpha$ values for all factor categories

\begin{tabular}{lc}
\hline Factor Category & Cronbach's $\alpha$ \\
\hline 1. Factors related to clients & 0.86 \\
2. Factors related to designers & 0.80 \\
3. Factors related to project managers & 0.84 \\
4. Factors related to contractors & 0.85 \\
5. Labour related labour & 0.77 \\
6. Problems of finance & 0.68 \\
7. Factors related to contractual matters & 0.83 \\
8. Problems of communication and information & 0.88 \\
9. Problems of site and environment & 0.82 \\
10. Problems of government and local authorities & 0.87 \\
11. Other factors & 0.79 \\
\hline
\end{tabular}

Cronbach's $\alpha$ value for all factor categories were $>0.70$, with the exemption of one (problems of finance) which is regarded as adequate proof of internal consistency. It should be noted that Cronbach's a values of 0.50 to 0.70 are acceptable for exploratory research. As indicated in Table 5, time delay may be small or large. The variation of Cronbach's coefficient suggests that the delay factor categories are unidimensional. Relative Importance Index (RII) was used to measure the level of importance of categories and variables. This method is widely used to arrange variables in terms of importance, agreement, severity and so on (Holt, 2013). Spearman's rank correlation was used to evaluate whether consensus of opinions exists between groups of respondents (client versus consultant, client versus contractor and consultant versus contractor). It measures and compares the association between the rankings of two parties for a single cause of delay, while ignoring the ranking of the third party. The coefficient can be computed as follows (Dowdy and Wearden, 1985): 


$$
r_{s}=1-\frac{6 \sum d^{2}}{N\left(N^{2}-1\right)}
$$

Where, $r_{s}$ is Spearman's rank correlation coefficient, $d$ is the difference in ranking given by any two respondents for an individual cause and $N$ is the number of causes and groups. The correlation coefficient varies between +1 and -1 , where +1 implies a perfect positive relationship (agreement), while -1 results from a perfect negative relationship (disagreement). Values near zero indicate little or no correlation. In each category, Spearman's correlation test was used to determine the relationship between the set of respondents used in this study. For instance as reported in category (1), the Spearman's correlation coefficient for client related factors suggested that the relationship between contractors and consultants are weak with $r_{s}$ value close to zero. There also seemed to be no agreement between clients and consultants, although the correlation between contractors and clients was moderately positive ( $r_{s}$ 0.655). Based on the overall results of Spearman's correlation, there was a moderate positive correlation between all parties. As shown in Table (6), there is a moderate positive correlation between all parties, which suggests that there is some agreement.

Table 6 - Ranking of causes (based on overall)

\begin{tabular}{|c|c|c|c|c|c|c|c|c|c|}
\hline \multirow[t]{2}{*}{ Ref } & \multirow[t]{2}{*}{ Delay Cause } & \multicolumn{2}{|c|}{ Contractors } & \multicolumn{2}{|c|}{ Consultants } & \multicolumn{2}{|c|}{ Clients } & \multicolumn{2}{|c|}{ Overall } \\
\hline & & RII & Rank & RII & Rank & RII & Rank & RII & Rank \\
\hline 1 & Factors Related to Client & & & & & & & & \\
\hline 1.1 & Unrealistic contract duration imposed by client & 0.859 & 1 & 0.789 & 4 & 0.817 & 2 & 0.841 & 1 \\
\hline 1.2 & Too many scope changes and change orders & 0.847 & 2 & 0.589 & 45 & 0.633 & 37 & 0.773 & 3 \\
\hline 1.3 & Slowness in decision making process by owner & 0.788 & 7 & 0.700 & 12 & 0.633 & 37 & 0.753 & 8 \\
\hline 1.4 & $\begin{array}{l}\text { Late in revising and approving design } \\
\text { documents by owner }\end{array}$ & 0.753 & 14 & 0.622 & 30 & 0.767 & 6 & 0.731 & 14 \\
\hline 1.5 & $\begin{array}{l}\text { Selection criteria for consultants and contractors } \\
\text { are based on cheapest price }\end{array}$ & 0.718 & 22 & 0.800 & 3 & 0.683 & 28 & 0.727 & 16 \\
\hline 1.6 & Confusing and ambiguous requirements & 0.676 & 34 & 0.833 & 2 & 0.533 & 78 & 0.688 & 24 \\
\hline 1.7 & Excessive bureaucracy/uncooperative owner & 0.694 & 26 & 0.600 & 40 & 0.733 & 17 & 0.682 & 27 \\
\hline 1.8 & Late handover of site & 0.682 & 29 & 0.578 & 56 & 0.650 & 32 & 0.659 & 33 \\
\hline 1.09 & Regular interference & 0.629 & 58 & 0.778 & 5 & 0.483 & 82 & 0.639 & 45 \\
\hline 1.10 & Delay in materials supplied by client & 0.700 & 25 & 0.467 & 75 & 0.517 & 80 & 0.635 & 51 \\
\hline 1.11 & Suspension of work by owner & 0.635 & 54 & 0.589 & 45 & 0.567 & 65 & 0.618 & 59 \\
\hline 1.12 & Delay of payment by client & 0.653 & 43 & 0.411 & 83 & 0.550 & 73 & 0.596 & 66 \\
\hline 2 & Factors related to designers & & & & & & & & \\
\hline 2.1 & Incomplete design at the time of tender & 0.829 & 3 & 0.678 & 13 & 0.750 & 9 & 0.792 & 2 \\
\hline 2.2 & Design changes & 0.800 & 5 & 0.633 & 22 & 0.633 & 37 & 0.749 & 9 \\
\hline 2.3 & $\begin{array}{l}\text { Poor Design management } \& \text { delay in producing } \\
\text { design documents }\end{array}$ & 0.759 & 13 & 0.656 & 16 & 0.750 & 9 & 0.739 & 11 \\
\hline 2.4 & $\begin{array}{l}\text { Delay in approving shop drawings and sample } \\
\text { materials }\end{array}$ & 0.765 & 11 & 0.522 & 72 & 0.550 & 73 & 0.694 & 21 \\
\hline 2.5 & $\begin{array}{l}\text { Mistakes, errors \& discrepancies in design } \\
\text { documents }\end{array}$ & 0.694 & 26 & 0.611 & 36 & 0.733 & 17 & 0.684 & 25 \\
\hline 2.6 & Inadequate design team experience & 0.682 & 29 & 0.589 & 45 & 0.750 & 9 & 0.673 & 28 \\
\hline 2.7 & Impractical and complicated design & 0.682 & 29 & 0.589 & 45 & 0.500 & 81 & 0.643 & 43 \\
\hline 3 & Factors related to Project Managers & & & & & & & & \\
\hline 3.1 & Poor project planning and control & 0.771 & 10 & 0.767 & 6 & 0.745 & 16 & 0.767 & 5 \\
\hline 3.2 & Inadequate duration of contract period & 0.776 & 9 & 0.589 & 45 & 0.750 & 9 & 0.739 & 11 \\
\hline 3.3 & Delay in instructions from consultants & 0.782 & 8 & 0.556 & 65 & 0.683 & 28 & 0.729 & 15 \\
\hline 3.4 & Lack of timely decisions and corrective actions & 0.765 & 11 & 0.578 & 56 & 0.733 & 17 & 0.727 & 17 \\
\hline 3.5 & Poor leadership on part of the project manager & 0.653 & 43 & 0.578 & 56 & 0.750 & 9 & 0.651 & 39 \\
\hline 3.6 & Inadequate experience of staff & 0.665 & 37 & 0.611 & 36 & 0.567 & 65 & 0.643 & 43 \\
\hline & & 15 & & & & & & & \\
\hline
\end{tabular}




\begin{tabular}{|c|c|c|c|c|c|c|c|c|c|}
\hline \multirow[t]{2}{*}{ Ref } & \multirow[t]{2}{*}{ Delay Cause } & \multicolumn{2}{|c|}{ Contractors } & \multicolumn{2}{|c|}{ Consultants } & \multicolumn{2}{|c|}{ Clients } & \multicolumn{2}{|c|}{ Overall } \\
\hline & & RII & Rank & RII & Rank & RII & Rank & RII & Rank \\
\hline 3.7 & Inadequate progress review & 0.624 & 61 & 0.600 & 40 & 0.767 & 6 & 0.637 & 48 \\
\hline 3.8 & Inaccurate project cost estimates & 0.641 & 50 & 0.600 & 40 & 0.650 & 32 & 0.635 & 51 \\
\hline 3.9 & Inflexibility (rigidity) of consultant & 0.647 & 46 & 0.567 & 62 & 0.567 & 65 & 0.622 & 54 \\
\hline 3.10 & Late approval of variations for payment & 0.641 & 50 & 0.556 & 65 & 0.600 & 52 & 0.620 & 56 \\
\hline 3.11 & $\begin{array}{l}\text { Delay in performing inspection and testing by } \\
\text { consultant }\end{array}$ & 0.647 & 46 & 0.533 & 71 & 0.600 & 52 & 0.620 & 56 \\
\hline 3.12 & Poor financial control on site & 0.618 & 63 & 0.589 & 45 & 0.583 & 61 & 0.608 & 62 \\
\hline 3.13 & Late preparation of Interim Certificates & 0.612 & 65 & 0.611 & 36 & 0.550 & 73 & 0.604 & 63 \\
\hline 4 & Factors related to Contractors & & & & & & & & \\
\hline 4.1 & Inadequate planning and scheduling & 0.747 & 15 & 0.844 & 1 & 0.783 & 4 & 0.769 & 4 \\
\hline 4.2 & $\begin{array}{l}\text { Inadequate site management, monitoring \& } \\
\text { control }\end{array}$ & 0.724 & 20 & 0.744 & 9 & 0.850 & 1 & 0.743 & 10 \\
\hline 4.3 & Lack of competent subcontractors/suppliers & 0.729 & 19 & 0.733 & 11 & 0.783 & 4 & 0.737 & 13 \\
\hline 4.4 & Late procurement of subcontractors \& materials & 0.741 & 16 & 0.589 & 45 & 0.817 & 2 & 0.722 & 18 \\
\hline 4.5 & $\begin{array}{l}\text { Lack of contractor's experience \& technical } \\
\text { staff }\end{array}$ & 0.712 & 23 & 0.756 & 7 & 0.667 & 31 & 0.714 & 19 \\
\hline 4.6 & Late Delivery of materials \& equipment & 0.682 & 29 & 0.622 & 30 & 0.617 & 44 & 0.663 & 32 \\
\hline 4.7 & Mistakes / Rework during construction & 0.659 & 40 & 0.656 & 16 & 0.650 & 32 & 0.657 & 36 \\
\hline 4.8 & Defective Work & 0.641 & 50 & 0.578 & 56 & 0.717 & 22 & 0.639 & 45 \\
\hline 4.9 & Delay in Site mobilization & 0.644 & 49 & 0.567 & 62 & 0.567 & 65 & 0.619 & 58 \\
\hline 4.10 & Delay payment to supplier/subcontractor & 0.600 & 68 & 0.622 & 30 & 0.600 & 52 & 0.604 & 63 \\
\hline 4.11 & $\begin{array}{l}\text { Damage of sorted material while they are } \\
\text { needed urgently }\end{array}$ & 0.565 & 81 & 0.578 & 56 & 0.750 & 9 & 0.590 & 69 \\
\hline 4.12 & Shortage of equipment $\&$ tools & 0.559 & 82 & 0.611 & 36 & 0.733 & 17 & 0.590 & 69 \\
\hline 4.13 & Shortage of materials in market & 0.618 & 63 & 0.467 & 75 & 0.567 & 65 & 0.584 & 71 \\
\hline 4.14 & Inappropriate construction methods & 0.582 & 75 & 0.556 & 65 & 0.600 & 52 & 0.580 & 73 \\
\hline 4.15 & Accidents during construction & 0.600 & 68 & 0.378 & 86 & 0.650 & 32 & 0.565 & 78 \\
\hline 4.16 & Equipment failure/breakdown & 0.594 & 74 & 0.378 & 86 & 0.567 & 65 & 0.551 & 81 \\
\hline 5 & Labour related factors & & & & & & & & \\
\hline 5.1 & Poor labour productivity problems & 0.806 & 4 & 0.633 & 22 & 0.700 & 26 & 0.761 & 7 \\
\hline 5.2 & Shortage of Skilled labour & 0.735 & 18 & 0.456 & 77 & 0.613 & 51 & 0.667 & 31 \\
\hline 5.3 & Severe overtime and shifts & 0.659 & 40 & 0.578 & 56 & 0.600 & 52 & 0.637 & 48 \\
\hline 5.4 & Absenteeism problems & 0.624 & 61 & 0.589 & 45 & 0.583 & 61 & 0.612 & 60 \\
\hline 5.5 & Poor relationship with labour & 0.635 & 54 & 0.478 & 74 & 0.600 & 52 & 0.602 & 65 \\
\hline 5.6 & High cost of labour & 0.576 & 78 & 0.444 & 78 & 0.600 & 52 & 0.555 & 80 \\
\hline 5.7 & Shortage of Unskilled labour & 0.541 & 84 & 0.378 & 86 & 0.600 & 52 & 0.518 & 85 \\
\hline 6 & Problems of Finance & & & & & & & & \\
\hline 6.1 & Financing difficulties of contractor & 0.676 & 34 & 0.756 & 7 & 0.617 & 44 & 0.684 & 25 \\
\hline 6.2 & Financing difficulties of owner & 0.671 & 36 & 0.644 & 20 & 0.683 & 28 & 0.667 & 30 \\
\hline 6.3 & $\begin{array}{l}\text { Effects of Global Economy/Unforeseeable } \\
\text { financial and economic crises }\end{array}$ & 0.629 & 58 & 0.744 & 9 & 0.700 & 26 & 0.659 & 33 \\
\hline 6.7 & $\begin{array}{l}\text { Increased cost due to high inflation during the } \\
\text { project }\end{array}$ & 0.582 & 75 & 0.633 & 22 & 0.617 & 44 & 0.596 & 66 \\
\hline 6.8 & Fluctuation in exchange rates & 0.435 & 89 & 0.422 & 81 & 0.483 & 82 & 0.439 & 89 \\
\hline 7 & Factors related to Contractual Matters & & & & & & & & \\
\hline 7.1 & Contract modifications & 0.659 & 40 & 0.678 & 13 & 0.617 & 44 & 0.657 & 36 \\
\hline 7.2 & Poor contract management & 0.629 & 58 & 0.656 & 16 & 0.717 & 22 & 0.645 & 42 \\
\hline 7.3 & Payment method during construction & 0.641 & 50 & 0.633 & 22 & 0.633 & 37 & 0.639 & 45 \\
\hline 7.4 & Inadequate definition of substantial completion & 0.665 & 37 & 0.589 & 45 & 0.550 & 73 & 0.637 & 48 \\
\hline 7.5 & Omission and errors in contract documents & 0.600 & 68 & 0.556 & 65 & 0.617 & 44 & 0.594 & 68 \\
\hline 7.6 & $\begin{array}{l}\text { Legal disputes \& Inappropriate method of } \\
\text { dispute resolution }\end{array}$ & 0.600 & 68 & 0.522 & 72 & 0.567 & 65 & 0.582 & 72 \\
\hline 7.7 & $\begin{array}{l}\text { Type of construction contract (Turnkey, } \\
\text { construction only, etc) }\end{array}$ & 0.582 & 75 & 0.589 & 45 & 0.550 & 73 & 0.580 & 73 \\
\hline 7.8 & Ineffective delay penalties & 0.606 & 67 & 0.400 & 84 & 0.583 & 61 & 0.565 & 78 \\
\hline 8 & Problems of Communication \& Information & & & & & & & & \\
\hline 8.1 & Slow information flow between parties & 0.741 & 16 & 0.644 & 20 & 0.633 & 37 & 0.710 & 20 \\
\hline 8.2 & $\begin{array}{l}\text { Poor communication /coordination between } \\
\text { consultant and other parties }\end{array}$ & 0.706 & 24 & 0.633 & 22 & 0.717 & 22 & 0.694 & 21 \\
\hline 8.3 & $\begin{array}{l}\text { Lack of communicating the requirements by } \\
\text { Owner }\end{array}$ & 0.724 & 20 & 0.656 & 16 & 0.567 & 65 & 0.692 & 23 \\
\hline 8.4 & $\begin{array}{l}\text { Poor communication and coordination by } \\
\text { contractor with other parties }\end{array}$ & 0.682 & 29 & 0.600 & 40 & 0.614 & 50 & 0.658 & 35 \\
\hline 9 & Problems of Site \& Environment & & & & & & & & \\
\hline 9.1 & Inadequate site investigation & 0.635 & 54 & 0.567 & 62 & 0.633 & 37 & 0.622 & 54 \\
\hline 9.2 & Poor safety conditions on site & 0.559 & 82 & 0.544 & 69 & 0.717 & 22 & 0.576 & 75 \\
\hline 9.3 & Poor site access or availability & 0.612 & 65 & 0.444 & 78 & 0.533 & 78 & 0.571 & 76 \\
\hline
\end{tabular}




\begin{tabular}{|c|c|c|c|c|c|c|c|c|c|}
\hline \multirow[t]{2}{*}{ Ref } & \multirow[t]{2}{*}{ Delay Cause } & \multicolumn{2}{|c|}{ Contractors } & \multicolumn{2}{|c|}{ Consultants } & \multicolumn{2}{|c|}{ Clients } & \multicolumn{2}{|c|}{ Overall } \\
\hline & & RII & Rank & RII & Rank & RII & Rank & RII & Rank \\
\hline 9.4 & Severe weather problems (hot, cold, rainy) & 0.600 & 68 & 0.422 & 81 & 0.600 & 52 & 0.567 & 77 \\
\hline 9.5 & Difficult site terrain to work & 0.535 & 85 & 0.633 & 22 & 0.483 & 82 & 0.547 & 82 \\
\hline 9.6 & Poor site layout & 0.576 & 78 & 0.444 & 78 & 0.383 & 87 & 0.529 & 84 \\
\hline 9.7 & $\begin{array}{l}\text { Effects of subsurface conditions (eg. soil, high } \\
\text { water table, etc.) }\end{array}$ & 0.576 & 78 & 0.367 & 89 & 0.350 & 88 & 0.510 & 86 \\
\hline 9.8 & $\begin{array}{l}\text { Lack of temporary facilities on site (buildings, } \\
\text { phones, electricity, etc.) }\end{array}$ & 0.506 & 87 & 0.389 & 85 & 0.450 & 85 & 0.478 & 88 \\
\hline 10 & Problems of Government \& Local Authorities & & & & & & & & \\
\hline 10.1 & $\begin{array}{l}\text { Delay in obtaining permit/approval from } \\
\text { municipality/different gov. authorities }\end{array}$ & 0.794 & 6 & 0.667 & 15 & 0.750 & 9 & 0.765 & 6 \\
\hline 10.2 & Routine of Government authorities & 0.635 & 54 & 0.622 & 30 & 0.767 & 6 & 0.649 & 40 \\
\hline 10.3 & $\begin{array}{l}\text { Discrepancy between design specification and } \\
\text { building code }\end{array}$ & 0.647 & 46 & 0.589 & 45 & 0.733 & 17 & 0.647 & 41 \\
\hline 10.4 & Government Policies & 0.600 & 68 & 0.622 & 30 & 0.650 & 32 & 0.610 & 61 \\
\hline 11 & Other Factors & & & & & & & & \\
\hline 11.1 & Lack of available resources & 0.688 & 28 & 0.633 & 22 & 0.617 & 44 & 0.669 & 29 \\
\hline 11.2 & Delay in special manufactured building material & 0.665 & 37 & 0.622 & 30 & 0.633 & 37 & 0.653 & 38 \\
\hline 11.3 & Poor quality control over project & 0.653 & 43 & 0.600 & 40 & 0.583 & 61 & 0.635 & 51 \\
\hline 11.4 & Force majeure and acts of God & 0.535 & 85 & 0.633 & 22 & 0.400 & 86 & 0.537 & 83 \\
\hline 11.5 & Fraudulent practices and kickbacks & 0.494 & 88 & 0.544 & 69 & 0.291 & 89 & 0.480 & 87 \\
\hline
\end{tabular}

Validity and reliability were achieved by first assessing the plausibility of construction delay variables in UAE. The verification took place after the interpretation of quantitative data, this involved presenting the findings to the main participants. The validation took place after the verification process. Construct validity was used to assess the validity of the measurement procedure (questionnaire). It is worth noting that there was a clear link between the construct and the measures that were used in this study. This involved creating clear and precise conceptual and operational definitions of the construct we were interested in (causative factors leading to construction project delays in the UAE). Rigour was achieved by engaging participants in UAE projects and focusing on verification and validation, this included responsiveness of the researchers during group discussions, methodological coherence, appropriate sampling frame and data analysis. The philosophical consideration of this research can be viewed from two broad perspectives. The first perspective was linked to the essential requirement of identifying construction delay variables in UAE. The second perspective was linked to proposing solutions to challenges identified in the UAE construction industry.

\section{Findings}

The findings are presented below under seven categories drawn from the raw quantitative data. The seven categories are summarised below: 
Table 7: Client Related (category ranking)

\begin{tabular}{|c|c|c|c|c|c|c|c|c|}
\hline \multirow[t]{2}{*}{ Delay Cause } & \multicolumn{2}{|c|}{ Contractors } & \multicolumn{2}{|c|}{ Consultants } & \multicolumn{2}{|c|}{ Clients } & \multicolumn{2}{|c|}{ Group } \\
\hline & RII & Rank & RII & Rank & RII & Rank & RII & Rank \\
\hline Unrealistic contract duration imposed by client & 0.859 & 1 & 0.789 & 3 & 0.817 & 1 & 0.841 & 1 \\
\hline Too many scope changes and changed orders & 0.847 & 2 & 0.589 & 8 & 0.633 & 6 & 0.773 & 2 \\
\hline Slowness in decision making process by owner & 0.788 & 3 & 0.700 & 5 & 0.633 & 6 & 0.753 & 3 \\
\hline Late in revising and approving design documents & 0.753 & 4 & 0.622 & 6 & 0.767 & 2 & 0.731 & 4 \\
\hline Selection based on cheapest price & 0.718 & 5 & 0.800 & 2 & 0.683 & 4 & 0.727 & 5 \\
\hline Confusing and ambiguous requirements & 0.676 & 9 & 0.833 & 1 & 0.533 & 10 & 0.688 & 6 \\
\hline Excessive bureaucracy/uncooperative owner & 0.694 & 7 & 0.600 & 7 & 0.733 & 3 & 0.682 & 7 \\
\hline Late handover of site & 0.682 & 8 & 0.578 & 10 & 0.650 & 5 & 0.659 & 8 \\
\hline Regular interference & 0.629 & 12 & 0.778 & 4 & 0.483 & 12 & 0.639 & 9 \\
\hline Delay in materials supplied by client & 0.700 & 6 & 0.467 & 11 & 0.517 & 11 & 0.635 & 10 \\
\hline Suspension of work by owner & 0.635 & 11 & 0.589 & 8 & 0.567 & 8 & 0.618 & 11 \\
\hline Delay of payment by client & 0.653 & 10 & 0.411 & 12 & 0.550 & 9 & 0.596 & 12 \\
\hline
\end{tabular}

Ranked in ascending order Table 7 presents the respondents rating of the influence of client related factors on project delivery time. The factor with the most significant influence is unrealistic contract duration imposed by clients. Surprisingly, even the clients themselves recognised it, as they ranked it first under this category, and second overall. The second highest ranked variable had to do with too many scope changes and variations. Changes in scope may be due to execution of incomplete designs which leads to variations (Oyedele and Tham, 2006). Lack of proper scope definition creates a potential for change or growth in scope during construction. This can be linked to the most significant factor as identified by the consultants, namely "confusing and ambiguous requirements" which is the ability to effectively brief the design team. The inadequacies emanating from the design stage due to poor client brief definitions invariably lead to rework and other problems during construction. Slowness in decision making process by clients was ranked overall third, whereas lateness in revising and approving design documents was ranked fourth. This can be linked to the seventh ranked factor namely, "excessive bureaucracy" in client organisations. The Spearman's correlation coefficient for client related factors suggest that the relationship between contractors and consultants are weak with $r_{s}$ value close to zero (see Table 8). There also seemed to be no agreement between clients and consultants, although the correlation between contractors and clients was moderately positive $\left(r_{s} 0.655\right)$.

Table 8: Spearman's rank correlation coefficient for Client related factors

\begin{tabular}{lcl}
\hline Data pair & $r_{\mathrm{s}}$ & Relationship \\
\hline Contractor - Consultant & 0.193 & weak \\
Contractor - Client & 0.655 & moderately Positive \\
Client - Consultant & 0.209 & weak \\
\hline
\end{tabular}


Category 2: Factors related to designers

Table 9: Factors related to designers (category ranking)

\begin{tabular}{|c|c|c|c|c|c|c|c|c|}
\hline \multirow[t]{2}{*}{ Delay Cause } & \multicolumn{2}{|c|}{ Contractors } & \multicolumn{2}{|c|}{ Consultants } & \multicolumn{2}{|c|}{ Clients } & \multicolumn{2}{|c|}{ Group } \\
\hline & RII & Rank & RII & Rank & RII & Rank & RII & Rank \\
\hline Incomplete design at the time of tender & 0.829 & 7 & 0.678 & 1 & 0.750 & 1 & 0.792 & 1 \\
\hline Design changes & 0.800 & 6 & 0.633 & 3 & 0.633 & 5 & 0.749 & 2 \\
\hline $\begin{array}{l}\text { Poor Design management \& delay in producing } \\
\text { design documents }\end{array}$ & 0.759 & 4 & 0.656 & 2 & 0.750 & 1 & 0.739 & 3 \\
\hline $\begin{array}{l}\text { Delay in approving shop drawings and sample } \\
\text { materials }\end{array}$ & 0.765 & 5 & 0.522 & 7 & 0.550 & 6 & 0.694 & 4 \\
\hline $\begin{array}{l}\text { Mistakes, errors \& discrepancies in design } \\
\text { documents }\end{array}$ & 0.694 & 3 & 0.611 & 4 & 0.733 & 4 & 0.684 & 5 \\
\hline Inadequate design team experience & 0.682 & 1 & 0.589 & 5 & 0.750 & 1 & 0.673 & 6 \\
\hline Impractical and complicated design & 0.682 & 1 & 0.589 & 5 & 0.500 & 7 & 0.643 & 7 \\
\hline
\end{tabular}

As illustrated in Table 9, the results indicated that the most significant designer-related factor is incomplete design at time of tender, followed by design changes. On the other hand clients and consultants themselves recognise that poor design management and delay in producing design documents are major cause of project delay. The probable reason for this is that clients often request unrealistic deadlines for designs, exacerbated by confusing and ambiguous requirements (Gould and Joyce, 2009). This leads to incomplete design and consultants may not appraise designs sufficiently. Subsequently, large margins of error will appear in the project drawings and specifications. Conflicts often appear between drawings from different disciplines because of lack of coordination. In addition, results indicate that selection of consultants is often based on the lowest price that may result in insufficient resources. This might support the contractors' notion that inadequate design team experience and impractical and complicated designs are major causes for delay. Based on the Spearman's correlation coefficient tests for design related factors, the results suggest that the strongest relationships are between clients and consultants, with a $r_{s}$ value of 0.617, which is a positive moderate correlation (see Table 10). As illustrated in Table 10, contractors and consultants also seem to be in agreement, with a $r_{s}$ value of 0.564 . There is no agreement between contractors and clients as the value was close to zero.

Table 10: Spearman's rank correlation coefficient for design related factors

\begin{tabular}{lcl}
\hline Data pair & $\mathrm{r}_{\mathrm{s}}$ & Relationship \\
\hline Contractor - Consultant & 0.564 & moderate positive \\
Contractor - Client & 0.168 & weak \\
Client - Consultant & 0.617 & moderate positive \\
\hline
\end{tabular}

\section{Category 3: Project manager related issues}

Poor project planning and control was ranked first in this category, mostly driven by the consultants own perceptions (see Table 11). On the other hand inadequate durations of contract period, is both ranked second for the contractor and clients. This might be indicative that the clients feel illadvised on issues of contract durations. While the client might impose unrealistic durations, it is also the project managers' duty to give appropriate advice. 
Table 11: Project manager related issues

\begin{tabular}{lcccccccc}
\hline Delay Cause & \multicolumn{2}{c}{ Contractors } & \multicolumn{2}{c}{ Consultants } & \multicolumn{3}{c}{ Clients } & \multicolumn{2}{c}{ Group } \\
\cline { 2 - 8 } & RII & Rank & RII & Rank & RII & Rank & RII & Rank \\
\hline Poor project planning and control & 0.771 & 3 & 0.767 & 1 & 0.745 & 4 & 0.767 & 1 \\
Inadequate duration of contract period & 0.776 & 2 & 0.589 & 6 & 0.750 & 2 & 0.739 & 2 \\
Delay in instructions from consultants & 0.782 & 1 & 0.555 & 12 & 0.683 & 6 & 0.729 & 3 \\
Lack of timely decisions and corrective actions & 0.765 & 4 & 0.578 & 8 & 0.733 & 5 & 0.727 & 4 \\
Poor leadership on part of the project manager & 0.653 & 6 & 0.570 & 9 & 0.750 & 2 & 0.651 & 5 \\
Inadequate experience of staff & 0.665 & 5 & 0.611 & 2 & 0.567 & 11 & 0.643 & 6 \\
Inadequate progress review & 0.624 & 11 & 0.600 & 4 & 0.767 & 1 & 0.637 & 7 \\
Inaccurate project cost estimates & 0.641 & 9 & 0.610 & 5 & 0.650 & 7 & 0.635 & 8 \\
Inflexibility (rigidity) of consultant & 0.647 & 7 & 0.567 & 10 & 0.567 & 11 & 0.622 & 9 \\
Late approval of variations for payment & 0.641 & 9 & 0.556 & 11 & 0.600 & 8 & 0.620 & 10 \\
Delay in performing inspection and testing & 0.647 & 7 & 0.533 & 13 & 0.600 & 8 & 0.620 & 10 \\
Poor financial control on site & 0.618 & 12 & 0.580 & 7 & 0.583 & 10 & 0.608 & 12 \\
Late preparation of Interim Certificates & 0.612 & 13 & 0.610 & 3 & 0.550 & 13 & 0.604 & 13 \\
\hline
\end{tabular}

Delays in receiving instructions from consultants and lack of timely decisions and corrective actions are ranked third and fourth respectively. This might be linked to the slow decision making and excessive bureaucracy by the clients (Hester et al., 1991). Poor leadership is ranked fifth, driven by the clients' opinion. The Spearman's correlation coefficient tests for project managers related factors indicate that the relationship between all parties are weak, as the values are close to zero (see Table 12).

Table 12: Spearman's rank correlation coefficient for project manager related factors

\begin{tabular}{lcl}
\hline Data pair & $r_{s}$ & Relationship \\
\hline Contractor - Consultant & $(0.106)$ & weak \\
Contractor - Client & 0.419 & weak \\
Client - Consultant & 0.019 & weak \\
\hline
\end{tabular}

Category 4: Factors related to contractors

Table 13: Factors related to contractors (category ranking)

\begin{tabular}{|c|c|c|c|c|c|c|c|c|}
\hline \multirow[t]{2}{*}{ Delay Cause } & \multicolumn{2}{|c|}{ Contractors } & \multicolumn{2}{|c|}{ Consultants } & \multicolumn{2}{|c|}{ Clients } & \multicolumn{2}{|c|}{ Group } \\
\hline & RII & Rank & RII & Rank & RII & Rank & RII & Rank \\
\hline Inadequate planning and scheduling & 0.747 & 1 & 0.844 & 1 & 0.783 & 3 & 0.769 & 1 \\
\hline $\begin{array}{l}\text { Inadequate site management, monitoring and } \\
\text { control }\end{array}$ & 0.724 & 4 & 0.744 & 3 & 0.850 & 1 & 0.743 & 2 \\
\hline Lack of competent subcontractors/suppliers & 0.729 & 3 & 0.733 & 4 & 0.783 & 3 & 0.737 & 3 \\
\hline Late procurement of subcontractors and materials & 0.741 & 2 & 0.589 & 9 & 0.817 & 2 & 0.722 & 4 \\
\hline Lack of contractor's experience and technical staff & 0.712 & 5 & 0.756 & 2 & 0.667 & 8 & 0.714 & 5 \\
\hline Late Delivery of materials and equipment & 0.682 & 6 & 0.622 & 6 & 0.617 & 11 & 0.663 & 6 \\
\hline Mistakes / Rework during construction & 0.659 & 7 & 0.656 & 5 & 0.650 & 9 & 0.657 & 7 \\
\hline Defective Work & 0.641 & 9 & 0.578 & 10 & 0.717 & 7 & 0.639 & 8 \\
\hline Delay in Site mobilization & 0.644 & 8 & 0.567 & 12 & 0.567 & 14 & 0.619 & 9 \\
\hline Delay payment to supplier/subcontractor & 0.600 & 11 & 0.622 & 6 & 0.600 & 12 & 0.604 & 10 \\
\hline $\begin{array}{l}\text { Damage of sorted material while they are needed } \\
\text { urgently }\end{array}$ & 0.565 & 15 & 0.578 & 10 & 0.750 & 5 & 0.590 & 11 \\
\hline Shortage of equipment and tools & 0.559 & 16 & 0.611 & 8 & 0.733 & 6 & 0.590 & 11 \\
\hline Shortage of materials in market & 0.618 & 10 & 0.467 & 14 & 0.567 & 14 & 0.584 & 13 \\
\hline Inappropriate construction methods & 0.582 & 14 & 0.556 & 13 & 0.600 & 12 & 0.580 & 14 \\
\hline Accidents during construction & 0.600 & 11 & 0.378 & 15 & 0.650 & 9 & 0.565 & 15 \\
\hline Equipment failure/breakdown & 0.594 & 13 & 0.378 & 15 & 0.567 & 14 & 0.551 & 16 \\
\hline
\end{tabular}

As shown in Table 13, the results indicate that there seems to be an agreement between contractors and consultants that inadequate planning and scheduling is the main cause for contractor delays. The second most significant factor is inadequate site management, monitoring 
and control. Lack of competent subcontractors / suppliers was ranked third. This is linked to the following factor, namely late procurement of subcontractors and materials. Validation feedback confirmed that due to a competitive market and low margins, procurement is often delayed in pursuit of commercial gains by negotiating discounts and seeking cheapest prices. Also it was noted that often ambiguity in specifications and late approvals by consultants delay placing orders. This has a knock-on effect in late delivery of materials and equipment, ranked sixth. Notably, a significant portion of subcontractor and materials related delays are MEP services related. Spearman's correlation coefficient for contractor related factors suggested that there was a moderate positive correlation between contractors and consultants $\left(r_{s} 0.659\right)$, while the relationship between contractors and clients were weak (see Table 14).

Table 14: - Spearman's rank correlation coefficient for contractor factors

\begin{tabular}{lcl}
\hline Data pair & $r_{\mathrm{s}}$ & Relationship \\
\hline Contractor - Consultant & 0.659 & moderate positive \\
Contractor - Client & 0.490 & weak \\
Client - Consultant & 0.607 & moderate positive \\
\hline
\end{tabular}

\section{Category 5: Labour related factors}

There was evidence of agreement between all the targeted stakeholders that poor labour productivity was the main issue of concern, ranked first (see Table15). The labour force of the UAE is primarily made up of foreign workers, with most of them coming from the Indian subcontinent and other parts of Asia (Ren et al., 2008). Feedback from the validation confirmed that not much time and money is spent on developing the skills of these workers, which correspond with the second ranked factor, shortage of skilled workers. Workers are often paid low salaries and the weather plays an important role on productivity outputs especially during summer months (Ren et al., 2008). Poor level of supervision was also noted as a reason for low labour productivity. Severe overtime and shifts, has been ranked third which also affects productivity. As a norm, contractors often work double shifts just to meet project durations.

Table 15: Labour related factors (category ranking)

\begin{tabular}{|c|c|c|c|c|c|c|c|c|}
\hline \multirow[t]{2}{*}{ Delay Cause } & \multicolumn{2}{|c|}{ Contractors } & \multicolumn{2}{|c|}{ Consultants } & \multicolumn{2}{|c|}{ Clients } & \multicolumn{2}{|c|}{ Group } \\
\hline & RII & Rank & RII & Rank & RII & Rank & RII & Rank \\
\hline Poor labour productivity problems & 0.806 & 1 & 0.633 & 1 & 0.700 & 1 & 0.761 & 1 \\
\hline Shortage of Skilled labour & 0.735 & 2 & 0.456 & 5 & 0.613 & 2 & 0.667 & 2 \\
\hline Severe overtime and shifts & 0.659 & 3 & 0.578 & 3 & 0.600 & 3 & 0.637 & 3 \\
\hline Absenteeism problems & 0.624 & 5 & 0.589 & 2 & 0.583 & 7 & 0.612 & 4 \\
\hline Poor relationship with labour & 0.635 & 4 & 0.478 & 4 & 0.600 & 3 & 0.602 & 5 \\
\hline High cost of labour & 0.576 & 6 & 0.444 & 6 & 0.600 & 3 & 0.555 & 6 \\
\hline Shortage of Unskilled labour & 0.541 & 7 & 0.378 & 7 & 0.600 & 3 & 0.518 & 7 \\
\hline
\end{tabular}


Spearman's correlation coefficient test for labour related factors suggested that the relationship between contractors and clients were highly correlated with a $r_{s}$ of 0.709 while clients and consultants had almost no correlation with a $r_{s}$ of 0.188 (see Table 16).

Table 16: Spearman's rank correlation coefficient for labour factors

\begin{tabular}{lcl}
\hline Data pair & $r_{s}$ & Relationship \\
\hline Contractor - Consultant & 0.679 & moderate positive \\
Contractor - Client & 0.709 & highly correlated \\
Client - Consultant & 0.118 & weak \\
\hline
\end{tabular}

Category 6: Finance related problems

As demonstrated in Table 17, the results suggested that the most influential factor in this category was financing difficulties of contractors. This can be a symptom of poor cash flow management. On the other hand financing difficulties associated with clients ranked second. The effects of global economy were ranked third, followed by increased cost due to high inflation during the project. Prices of commodities have stablisied over recent years. The least significant factor in this category is fluctuation in exchange rates. The UAE currency (Dirham) is pegged to the US dollar which gives it some protection against currency fluctuations.

Table 17: Finance related problems

\begin{tabular}{|c|c|c|c|c|c|c|c|c|}
\hline \multirow[t]{2}{*}{ Delay Cause } & \multicolumn{2}{|c|}{ Contractors } & \multicolumn{2}{|c|}{ Consultants } & \multicolumn{2}{|c|}{ Clients } & \multicolumn{2}{|c|}{ Group } \\
\hline & RII & Rank & RII & Rank & RII & Rank & RII & Rank \\
\hline Financing difficulties of contractor & 0.676 & 1 & 0.756 & 1 & 0.617 & 3 & 0.684 & 1 \\
\hline Financing difficulties of owner & 0.671 & 2 & 0.644 & 3 & 0.683 & 2 & 0.667 & 2 \\
\hline $\begin{array}{l}\text { Effects of Global Economy/Unforeseeable financial } \\
\text { and economic crises }\end{array}$ & 0.629 & 3 & 0.744 & 2 & 0.700 & 1 & 0.659 & 3 \\
\hline $\begin{array}{l}\text { Increased cost due to high inflation during the } \\
\text { project }\end{array}$ & 0.582 & 4 & 0.633 & 4 & 0.617 & 3 & 0.596 & 4 \\
\hline Fluctuation in exchange rates & 0.435 & 5 & 0.422 & 5 & 0.483 & 5 & 0.439 & 5 \\
\hline
\end{tabular}

There was a very strong correlation between contractors and consultants demonstrating agreements in terms of finance related factors where $r_{s}$ was 0.9 . The correlation between clients and consultants were however moderately positive, while the weakest correlation was between contractors and clients with a $r_{s}$ value of 0.462 (see Table 18).

Table 18: Spearman's rank correlation coefficient for finance factors

\begin{tabular}{lcl}
\hline Data pair & $r_{\mathrm{s}}$ & Relationship \\
\hline Contractor - Consultant & 0.900 & highly correlated \\
Contractor - Client & 0.462 & Weak \\
Client - Consultant & 0.564 & moderate positive \\
\hline
\end{tabular}

Category 7: Factors related to contractual matters

Contract modifications were noted as the main contributing factor of delays on contractual matters (see Table 19). The contract is the main mechanism for transferring risk, and it can be interpreted that unreasonable requirements drive contract modifications. Poor contract management was 
identified as the second most significant factor while payment methods during construction were ranked third in this category. One responded noted that many suppliers insist on Letter of Credit (LC) payment, which requires the banks to secure the full value prior to delivery. This reduces working capital and takes time to process.

Table 19: Factors related to contractual matters (category ranking)

\begin{tabular}{|c|c|c|c|c|c|c|c|c|}
\hline \multirow[t]{2}{*}{ Delay Cause } & \multicolumn{2}{|c|}{ Contractors } & \multicolumn{2}{|c|}{ Consultants } & \multicolumn{2}{|c|}{ Clients } & \multicolumn{2}{|c|}{ Group } \\
\hline & RII & Rank & RII & Rank & RII & Rank & RII & Rank \\
\hline Contract modifications & 0.659 & 2 & 0.678 & 1 & 0.617 & 3 & 0.657 & 1 \\
\hline Poor contract management & 0.629 & 4 & 0.656 & 2 & 0.717 & 1 & 0.645 & 2 \\
\hline Payment method during construction & 0.641 & 3 & 0.633 & 3 & 0.633 & 2 & 0.639 & 3 \\
\hline Inadequate definition of substantial completion & 0.665 & 1 & 0.589 & 4 & 0.550 & 7 & 0.637 & 4 \\
\hline Omission and errors in contract documents & 0.600 & 6 & 0.556 & 6 & 0.617 & 3 & 0.594 & 5 \\
\hline $\begin{array}{l}\text { Legal disputes \& Inappropriate method of dispute } \\
\text { resolution }\end{array}$ & 0.600 & 6 & 0.522 & 7 & 0.567 & 6 & 0.582 & 6 \\
\hline $\begin{array}{l}\text { Type of construction contract (Turnkey, } \\
\text { construction only, etc) }\end{array}$ & 0.582 & 8 & 0.589 & 4 & 0.550 & 7 & 0.580 & 7 \\
\hline Ineffective delay penalties & 0.606 & 5 & 0.400 & 8 & 0.583 & 5 & 0.565 & 8 \\
\hline
\end{tabular}

Inadequate definition of substantial completion was ranked fourth in this category. However, contractors believed that this was their most influential factor. Their responses suggested that the taking over certificate was often delayed until after government authorities had completed the final inspections. Minor defects were often used to delay retention release for as long as possible, and had the contractor commit to a longer defects liability period. By delaying the taking over certificate and on the argument of concurrent delays, it becomes more difficult for contactors to support delay claims. Spearman's correlation coefficient tests for contract related factors suggested that the overall relationship between parties were weak, with the exception of contractor and consultants which was moderately positive at $r_{s} 0.530$.

Table 20: Spearman's rank correlation coefficient for contractual matters

\begin{tabular}{lcl}
\hline Data pair & $r_{s}$ & Relationship \\
\hline Contractor - Consultant & 0.530 & moderate positive \\
Contractor - Client & 0.224 & weak \\
Client - Consultant & 0.485 & Weak \\
\hline
\end{tabular}

Category 8: Problems of government and local authorities

There was general consensus between contractors and consultants that delay in obtaining building permits and approvals from municipalities and different government departments was the most significant cause of delay in this category (see Table 21). Overall this was the sixth most important factor from all delay factors. This was followed in this category by routine procedures of government departments. 
Table 21: Problems of government and local authorities

\begin{tabular}{|c|c|c|c|c|c|c|c|c|}
\hline \multirow[t]{2}{*}{ Delay Cause } & \multicolumn{2}{|c|}{ Contractors } & \multicolumn{2}{|c|}{ Consultants } & \multicolumn{2}{|c|}{ Clients } & \multicolumn{2}{|c|}{ Group } \\
\hline & RII & Rank & RII & Rank & RII & Rank & RII & Rank \\
\hline $\begin{array}{l}\text { Delay in obtaining permit/approval from } \\
\text { municipality/different gov. authorities }\end{array}$ & 0.794 & 1 & 0.667 & 1 & 0.750 & 2 & 0.765 & 1 \\
\hline Routine of Government authorities and approvals & 0.635 & 3 & 0.622 & 2 & 0.767 & 1 & 0.649 & 2 \\
\hline $\begin{array}{l}\text { Discrepancy between design specification and } \\
\text { building code }\end{array}$ & 0.647 & 2 & 0.589 & 4 & 0.733 & 3 & 0.647 & 3 \\
\hline Government Policies & 0.600 & 4 & 0.622 & 2 & 0.650 & 4 & 0.610 & 4 \\
\hline
\end{tabular}

Based on Spearman's correlation coefficient tests for government and local authorities related factors, the relationship between all parties were found to be weak, with values close to zero.

Table 22: Spearman's rank correlation for government and local authorities

\begin{tabular}{lcl}
\hline Data pair & $r_{s}$ & Relationship \\
\hline Contractor - Consultant & 0.316 & weak \\
Contractor - Client & 0.400 & weak \\
Client - Consultant & 0.316 & weak \\
\hline
\end{tabular}

\section{Discussion}

This paper examined the attitudes and experiences of construction delay amongst clients and senior construction practitioners in UAE. The findings from this study show that the construction industry has always suffered from fragmentation owing to the temporary nature of project execution (Sullivan and Harris, 1985). The effects of fragmentation can be mitigated, by adopting a project strategy which will combine the skills of individuals and groups from contributing organisations so as to have the best balance of resources available at the right time. In this study, the following were identified as top construction delay variables in UAE:

- Unrealistic contract duration imposed by client;

- Incomplete design at the time of tender;

- Too many scope changes and change orders;

- Inadequate planning and scheduling (by contractors);

- Poor project planning and control (by Project Managers);

- Delay in obtaining permit/approval from municipality /different government. authorities;

- Poor labour productivity problems;

- Slowness in decision making process by owner;

- Design changes; and

- Inadequate site management, monitoring and control.

Under the category related to 'Clients', the most significant delay cause was "unrealistic contract duration imposed by clients". It was expressed that political expediency is often driving unreasonable project timeframes, without consideration of how these projects will be resourced. The second most important variable in this category was "too many scope changes and variations". As evidenced from the findings, change in scope was due to execution of incomplete designs which leads to variations. Further, lack of proper scope definition creates a potential for 
change or growth in scope during construction. This was followed by "slowness in decision making process by clients", and "late in revising and approving design documents" which was ranked third and fourth in the category related to clients. This can be linked to excessive bureaucracy in client organisations. Surprisingly, "delay in payment by the client" did not have any significant influence on project delay.

In the category related to designers results indicated that the most significant factor in this category was "incomplete design at time of tender". The probable reason for this was poor design management and unrealistic deadlines imposed by clients. Under the category related to 'Project Managers', the most significant effect on project delay was "poor project planning and control", influenced by the consultants own perception. This interrelated with contractors and client's opinion that "inadequate duration of contract period", as determined by the project manager as more important. It can be indicative that the clients feel ill-advised on the contract durations proposed by project managers. While the clients might impose unrealistic durations, it is also the project manager duty to advise them correctly. Poor leadership was pointed out by the clients as a concern, which is evident that clients are generally not happy with the way projects are managed.

Under the category related to 'Contractors', inadequate planning and scheduling was the main cause for contractor's delays. Commitment by contractors to enter into contracts with very tight timeframes might be due to pressures from a competitive market, over optimism or inability to plan properly during tender phase. The second most significant factor in this category was inadequate site management, monitoring and control. These factors signified that the traditional way of managing projects is not sufficient to cope with the pressures of complex and fast-track projects. Under the category related to 'Labour', there was agreement between all parties that poor labour productivity is the main issue of concern. Labourers are often paid low salaries and the weather plays an important role on productivity outputs especially during summer months. Poor level of supervision was also noted as a reason for low labour productivity. Similarly, severe overtime and shifts, negatively affects productivity.

On the issue of 'Finance' related problems the most influential factor was financing difficulties of contractors. This appeared to have no relation with late payment by clients and can be a symptom of poor cash flow management. With relation to the category related to 'Contractual matters', contract modifications was noted as the main contributor of delays. The contract is the main mechanism for transferring risk, and it can be interpreted that unreasonable demands drives contract modifications, due to disagreement. With regards to 'Government and Local Authorities', there was general consensus between contractors and consultants that delay in obtaining building permits and approvals was the most significant cause of delay in this category. 
These results suggest that construction delays in UAE are project and operational related. However, the Spearman's rank correlation coefficient tests were used to measure the degree of agreement or disagreement between the parties. Based on the overall results there was a moderate positive correlation between all parties. It was evident however that practitioners need to change their existing practices in order to ensure timely delivery of projects. Continuous coordination and relationship between practitioners are required through the project life cycle in order to solve problems and develop project performance. Practitioners should endeavour to use the already existing information in the public domain and develop means and ways of addressing the problems faced by the industry. As it is a known fact that there is not a single system that would work for all construction projects, adaptation of well aligned project tools and techniques is essential. As evidenced in this study, construction projects in UAE require clients and senior project practitioners with excellent coordination skills that are not limited to organising plant, materials and work items but also the human resource, which to a greater extent, have a significant impact on project outcomes.

It is recommended to develop human resources in the construction industry through proper and continuous training programs. These programs can update their knowledge and can assist them to be more familiar with project management techniques and processes. Parties must recognise the advantage of collaboration and be open minded and willing to join the collaboration. Every party must be aware that collaboration has a huge potential to minimize risks and maximize opportunities. As affirmed by Flyvbjerg (2014), Ochieng and Price (2010) and Ochieng et al. (2013c), a bad project with an excellent project team, has a higher chance of being completed on time than a "good" contract executed by a "bad" team. An incentive system can help to build strong, trustful, and sustainable relationships between the construction parties. A comparison of the findings of this study against those of previous researchers on the subject suggested that there were significant differences in factors causing construction project delays based on geographic, cultural, and socio-economic factors. This accord with an earlier observation that construction projects can be country-specific (Sambasivan and Soon, 2007). There also appears to be time dimension to the relevance of such pieces of research because an earlier study by Faridi and ElSayegh (2006) on the UAE construction industry yielded fundamentally different results from what this study has found out.

As demonstrated in the method section, the number of unit's analysis in this study was dictated by the type of research problem. According to Creswell (2003), if the sample size is too small, it becomes difficult to find significant relationships from the data, as statistical tests normally require larger sample size to ensure representative distribution of the population and to be considered representative of groups of people to whom results will be generalised or transferred. As articulated in Faridi et al. (2006) study, the questionnaire forms were distributed to 400 randomly 
selected construction professionals. A total of 105 responses were received, thus a response rate of 27 per cent was received. In this study, the population consisted of approximately 500 experienced stakeholders (clients, consultants and contractors). A total of 208 responses were received, giving a response rate of 42 percent. In addition, a number of statistical techniques were used to analyse the data collected from the participants. The first was the reliability using Cronbach's alpha coefficient. The Cronbach's coefficient test was used to test the reliability of the 5-point Likert scale for all variables under each category. Faridi et al. (2006), fails to address this specific issue. The second one was Relative Importance Index (RII) to measure the level of importance of variables indicated by respondents. Relative Importance Index (RII) was used to measure the level of importance of categories and variables. In the previous study, Relative Importance Index (RII) was used to analyse causes of delay, ranking was based on contractors and consultants.

\section{Conclusion}

The present study was designed to identify the most significant causes of delays in the UAE construction industry. The study has unveiled a number of important causes of construction delays in the UAE, ranging from unrealistic contract durations to poor labour productivity, with consultants and clients seemingly shouldering the bulk of the 'blame game'. It was evident however that all the three main stakeholders in a construction project (clients, consultants and contractors) need to change their existing practices in order to ensure timely delivery of projects. A comparison against previous international literatures on project delays was conducted in an attempt to determine differences in causes based on geographic, cultural and socio-economic factors. The causative factors of project delays obtained through survey were compared against the top-five important factors from previous studies (see Table 2). The research confirms that delays are country specific and appear to be time related hence they should be viewed within the social, economic and cultural settings of the United Arab Emirates. The results are not fully comparable to any of the studies which support Sambasivan and Soon (2007) findings that "the effects of delays in construction projects can be country-specific". Further, it also appear to be time related since an earlier study by Faridi et al. (2006) on the UAE, is significantly different. In order to successfully address issues of project delays, the casual factors need to be clearly understood at the planning phase. There are a number of important changes which need to be made in UAE. Methods should be put in place to reduce long and bureaucratic processes within the client's organisations, not only to fulfil the requirements of the contract but also to suit fast-track projects.

Mechanisms should be in place to reduce mistakes and discrepancies in design documents. There is a need for more team building, knowledge exchange and a greater integration of skills particularly at the early stages of planning a project and developing its design. Inadequate project management expertise by project managers may prove to be a recipe for unsuccessful projects. 
There is need to ensure that personnel or consultants managing construction projects have the necessary training in construction project management. During tendering it is advised that contractors engage experienced members within their organisation from the production side, such as project managers, site agents, engineers, etc. to establish an adequate programme and resource allocation for the fulfilment of the project. Considerably more work will need to be done to propose a performance measurement framework which would allow practitioners in UAE to benchmark their construction processes.

The findings of this study have a number of important implications for future practice. To avoid delay in reviewing and approving design documents, methods should be put in place to reduce long and bureaucratic processes within the client's organization. In addition, construction clients should hire specialist's contractors with whom they have a good relationship. From a designer standpoint, there is a need for more team building, knowledge exchange and a greater integration of skills particularly at the development phase of construction projects. In order to enhance project performance, continuous coordination and relationship between client, project manager and specialists contractors are required throughout the project life cycle. As demonstrated in this study, the construction industry has always suffered from fragmentation owing to the temporary nature of project execution. The effects of fragmentation can be mitigated, by adopting a project strategy which will amalgamate the skills of specialist's contractors from contributing organisations. The project manager should also ensure that there is adequate construction time and sufficient float that has been built into the programme so that when delays do occur, they are absorbed into the contract and are less likely to become critical. It is suggested that construction project managers should utilise flexible programmes and focus more on project objectives to be achieved.

There are some issues that were not covered in-depth but have been identified as themes for subsequent research. These issues have been outlined as very specific recommendations for further research. There is a need for the construction industry in UAE to develop further its understanding of project complexity at different levels (strategic, operational and project). This calls for comprehensive research into the application of value enhancing practices. Although there has been significant research into operational efficiency in Western economies, there has been little done to address this theme in developing countries. This highlights the need for research work examining how operational efficiency can be achieved on construction projects in UAE. A major limitation of the current study was the use of a single approach to facilitate data collection. As suggested by Creswell (2003) studies that use a mixed method are more reliable because they engage triangulation.

\section{References}


Abdel-Wahab, M. S., Dainty, A. R. J., Ison, S. G., Bowen P, and Hazlehurst, G. (2008). Trends of skills and productivity in UK construction Industry. Engineering, Construction and Architectural Management, 15(4), 372-382.

Abdul-Rahman, H., Berawi, M. A., Berawi, A. R., Mohamed, O., Othman, M., and Yahya, I. A, (2006). Delay mitigation in the Malaysian construction industry. Journal of Construction Engineering Management, 132(2), 125-133.

Acharya, N. K, Lee, Y. D, and Im, H. M, (2006). Conflicting factors in construction project: Korean perspective. Engineering, Construction and Architectural Management, 13(6), 543-566.

Ahmed, S. M., Azhar, S., Kappagantula, P. and Gollapudi, D. (2003). "Delays in construction: A brief study of the Florida construction industry." Proceeding of the $39^{\text {th }}$ Annual ASC Conference, Clemson University, Clemson, SC, 257-266.

Al-Aghbari, W. A. M. (2005). Factors affecting construction speed of industrialised building systems in Malaysia. Master's thesis, University Putra Malaysia.

Al-Kharashi, A. and Skitmore, M. (2008). Causes of delays in Saudi Arabian public sector construction projects. Construction Management and Economics, 27(1), 3-23.

Alwi, S. and Hampton, K. (2003). "Identifying important factors causes of delays in building construction projects." The $9^{\text {th }}$ East Asia-Pacific Conference on Structural Engineering and Construction, Bali, Indonesia.

Andi, T. and Minato, T. (2003). Representing Causal Mechanism of Defective Designs: A System Approach Considering Human Errors. Construction Management and Economics, 21(3), 297-305.

Arditi, R. D, Akan, G. T. and Gurdamar, S. (1985). Reasons for delays in public projects in Turkey. Construction Management and Economics, 3(2), 171-181.

Assaf, S. A., Al-Khalil, M. and Al-Hazmi, M. (1995). Causes of delay in large building construction projects. Journal of Management in Engineering, 11(2), 45-50.

Assaf, S. A and Al-Hejji, S. (2006). Causes of delay in large building construction projects. International Journal of Project Management, 24(4), 349-357.

Ayudhya, B.I.N. (2011). Evaluation of common delay causes of construction projects in Singapore. Journal of Civil Engineering and Architecture, 5(11), 1027-1034.

Belout, A. and Gauvreau, C. (2004). Factors influencing project success: The impact of human resource management. International Journal of Project Management, 22(1), 1-11.

Blismas, N. G, Sher, W. D, Thorpe, A. and Baldwin, A. N. (2004). Factors nfluencing project delivery within construction clients multi-project environments. Engineering, Construction and Architectural Management, 11(2), 113-125.

Business Monitor International (BMI 2013). UAE construction industry valued at $\$ 41 \mathrm{bn}$ in 2013. http://www.constructionweekonline.com/article-24518-uae-construction-industry-valued-at-41bn-in2013/ [Accessed $5^{\text {th }}$ July 2015]. 
Business Round Table, (1991). Scheduled overtime effect on construction projects. Construction Industry Cost Effectiveness Report C-2, New York.

Chan, W. M. C. and Kumaraswamy, M. M. (2002). Compressing construction durations: lessons learned from Hong Kong building projects. International Journal of Project Management, 20(1), 2335.

Chan, A. P. C, Scott D, and Chan, A. P. L, (2004). Factors affecting the success of a construction project. Journal of Construction Engineering and Management, 130(1), 153-155.

CIDB (1992). Raising Singapore's Construction Productivity CIDB Construction Productivity Taskforce Report, Construction Industry Development Board, Singapore.

Couto, J. P. and Teixeira, J. C. (2007). "The evaluation of the delays in the Portuguese construction." CIB World Building Congress.

Cox. A. and Townsend. M (1997). Latham as half way house: A relational competence approach to better practice in construction procurement. Engineering, Construction and Architectural Management, 4(2), 143-158.

Creswell, J. (2003). Research design: Qualitative, quantitative and mixed methods approaches (2nd ed.). Thousand Oaks, CA: Sage Publications.

Cronbach, L. J. (1951). Coefficient alpha and the internal structure of tests. Psychometrika, 16(3), 297-334.

Dai. J, Goodrum, P. M, and Maloney, W. (2007). Analysis of Craft Workers' and Foremen's perceptions of the Factors Affecting Construction Labour Productivity. Construction Management and Economics, 25(11), 1139-1152.

Danso, H. and Antwi, J. K. (2012). Evaluation of the factors influencing time and cost overruns in telecom tower construction in Ghana. International Institute for Science, Technology \& Education (IISTE), Civil and Environmental Research, 2(6), 2012.

Dawnays Ltd v F G Minter Ltd. (1971). 2 All ER 1389.

Delamont, S. Atkinson, P. and Parry, O. (1997). Supervising the PhD: A Guide to Success, The Society for Research into Higher Education, Open University Press, Maidenhead.

Dowdy, S. and Wearden, S. (1985). Statistics for research. $2^{\text {nd }}$ Ed. John Wiley and Sons, New York.

Eldin, N. N. (1999). Impact of employee management and process issues on constructability implementation. Construction Management and Economics, 17 (6), 711-720.

Elgohary M, Fairclough. N and Ricciuti, R (2003). Constructability - from Qinshan to the ACR. Nuclear Plant Journal, 21(5), 31-35.

Faniran, O. O, Oluwoye, J. O, and Lenard, D. (1994). Effective construction planning, Construction Management and Economics, 12(6), 485-499. 
Faridi, A. S and El-Sayegh, S. M. (2006). Significant factors causing delay in the UAE construction industry. Construction Management and Economics, 24(11), 1167-1176.

Fatoye, E. O. (2012). "Contributing factors of delay in the Nigerian construction industry: A comparative analysis with other selected countries." Procs $4^{\text {th }}$ West Africa Built Environment Research (WABER) Conference, 24-36 July 2012, Abuja, Nigeria, 575-587.

Flanagan, R., Norman, G., Ireland, V., and Ormerod, R., (1986). A fresh Look at the UK and US construction industry building employer's confederation, UK, London.

Flyvbjerg, B. (2014). What you should know about megaprojects and why: An overview. Project Management Journal, 45(2), 6-19.

Francis, V. E., Mehrtens, V. M., Sidwell, A, C. and McGeorge, W.D. (1999). Constructability strategy for Improved project performance. Architectural Science Review, 42, 133-138.

Frimpong, Y., Oluwoye, J. and Crawford, L. (2003). Causes of delay and cost overruns in construction of groundwater projects in developing countries: Ghana as a case study. International Journal of Project Management, 21 (5), 321-326.

Fugar, F. D. K, and Agyakwah-Baah, A. B. (2010). Delays in building construction projects in Ghana. Australasian Journal of Construction Economics and Building, 10(1/2), 128-141.

Gill, J. and Johnson, P. (2002). Research methods for managers. $3^{\text {rd }}$ Edn. Sage Publications. London.

Gould, F. and Joyce, N. (2009). Construction Project Management. ( $3^{\text {rd }}$ Ed). Pearson, Prentice Hall, New Jersey, USA..

Groak, S. (1994). Is construction an Industry? Notes towards a greater analytic emphasis on external linkages. Construction Management and Economics, 12, 287-293.

Hester, W. T, Kuprenas, J. A. and Chang, T. C, (1991). Construction Changes and Change Orders: Their Magnitude and Impacts. University of California, Berkeley,.

Holt, G. D. (2013). Asking questions, analysing answers: Relative importance revisited. Construction innovation, 14(1), 2-16.

Hsieh, T., Lu, S., and Wu, C. (2004). Statistical ananlysis of causes for change orders to metropolitan public works. International Journal of Project Management, 22, 679-686.

Kazaz, A. and Ulubeylis, S. (2003). A different approach to construction labour in Turkey: Comparative productivity analysis. Building and Environment, 39(1), 93-100.

Knight, A. and Ruddock, L. (2009). Advanced research methods in the built environment, Chichester: Wiley-Blackwell Publisher.

Kline, P. (1999). The handbook of psychological testing. ( $2^{\text {nd }}$ Ed.). Routledge, London. 
Latham, M. (1994). Constructing the Team, HMSO, London, 87-92.

Laufer, A., Howell, G. A. and Rosenfeld, Y. (1992). Three modes of short-term construction planning. Construction Management and Economics, 10(3), 249-262.

Le-Hoai, L., Lee, Y. D. and Lee, J. Y. (2008). Delay and cost overruns in Vietnam large construction projects: A comparison with other selected countries. Korean Society of Civil Engineers (KSCE) Journal of Civil Engineering, 12(6), 367-377.

Lim, E. H. and Ling, F.Y.Y. (2002). Model for predicting clients contribution to project success. Engineering Construction and Architectural Management, 9, 388-395.

Long, N. D., Ogunlana. S., Quang. T. and Lam. K. C. (2004). Large construction projects in developing countries: a case study from Vietnam. International Journal of Project Management, 22 (7), 553-561.

Loosemore. M., Hall, C. and Dainty, A. R. J. (1996). "Excitement, innovation and courage in construction management research - Challenging historical values." in Thorpe, A. (Ed.) Proceedings of the $12^{\text {th }}$ Annual ARCOM Conference, Sheffield Hallam, 418-427.

Low, S. P. and Abeyegoonasekera, B. (2001). Integrating Buildability in ISO 9000 Quality Management Systems: Case Study of a Condominium Project. Building and Environment, 36(3), 299-312.

Love, P., Wang, X., Sing, C. and Tiong, R. (2013). Determining the probability of project cost overruns. Journal of Construction Engineering and Management, 139 (3), 321-330.

Marzouk, M.M. and El-Rasas, T. (2014). Analysing delay causes in Egyptian construction projects. Journal of Advanced Research, 5 (1), 49-55.

Ochieng, E. G. and Price, A. D. F. (2009). Framework for managing multicultural project teams. Engineering Construction and Architectural Management, 16 (6), 527-543.

Ochieng, E. G. and Price, A. D. F. (2010). Managing cross-cultural communication in multicultural construction project teams: The case of Kenya and UK. International Journal of Project Management, 28 (5), 449-460.

Ochieng, E. G., Price, A. D. F and Moore, D. (2013a). Management of Global Construction Projects. Palgrave Macmillan's Global Academic, Hampshire, UK.

Ochieng, E. G., Price, A. D. F., Ruan, X., Melaine, Y. and Egbu, C. (2013b).The impact of crosscultural factors on heavy engineering projects: Case Kenya and UK. International Journal of Information Technology and Management, 4 (3), 1-21.

Ochieng, E. G., Price, A. D. F., Ruan, X., Egbu, C. O. and Moore, D. (2013c). The effect of uncertainty and complexity within multicultural construction teams. Engineering Construction and Architectural Management, 20 (3), 307-324.

O'Connor, J. T, and Yang L, (2004). Project performance versus Use of technologies at project and phase levels. Journal of Construction Engineering and Management, 130(3), 322-329.

Oglesby, C. H. (1989). Productivity Improvement in Construction, McGraw-Hill, New York. 
Oyedele, L. O. and Tham, K. W. (2006). Clients' assessment of architects' performance in building delivery process: Evidence from Nigeria. Building and Environment, 42(5), 2090-2099.

Phua, F. T. T. (2005). Determining the relationship between fee structure and project performance between firms: An empirical study based on institutional and task environment perspectives. Construction Management and Economics, 23(1), 45-56.

Pongpeng, J. and Liston, J. (2003). Contractor ability criteria: A review from the Thai construction industry. Construction Management and Economics, 21(3), 267-282.

Proverbs, D. G. and Holt, G. D. (2000). A theoretical model for optimum project (time) performance based on European best practice. Construction Management and Economics, 18(6), 657-665.

Rahman, I. A., Memon, A. H. , Azis, A. A. and Abdullah, N. H. (2013). Modelling causes of cost overrun in large construction projects with partial least square-SEM approach: Contractor's perspective. Research Journal of Applied Sciences, Engineering and Technology, 5(6), 19631972.

Ren, Z., Atout, M. and Jones, J. (2008). "Root causes of construction project delays in Dubai." Dainty, A (Ed) Procs 24th Annual ARCOM Conference, 1-3 September 2008, Cardiff, UK, Association of Researchers in Construction Management, 2, 749-757.

Sambasivan, M. and Soon, Y. W. (2007). Causes and effects of delays in Malaysian construction industry. International Journal of Project Management, 26, 665-674.

Santoso, D. S., Ogunlana S. O., and Minato, T. (2003). Assessment of risks in high rise building construction in Jakarta. Engineering, Construction and Architectural Management, 10(1), 43-55.

Sekran, U. (1992). Research methods for business: A skill building approach. Chichester: John Wiley and Sons.

Shebob, A., Dawood, N., Shah, R. K., \& Xu, Q. (2012). Comparative study of delay factors in Libyan and the UK construction industry. Engineering, Construction and Architectural Management, 19(6), 688-712.

Smith, T. E. (1999). "Collaborative Effort in Enhancing Building Quality." Housing Conference: Better Homes in the Next Millennium. Hong Kong, 24-25 November.

Speaight, A. (2010). Legal Handbook: The Law for Architects. $10^{\text {th }}$ Ed. Elsevier Limited, Oxford, UK.

Sullivan, A. and Harris, F. C, (1985). Delays on large construction projects, University of Technology, Loughborough, UK.

Sweis, G.J. (2013). Factors affecting time overruns in public construction projects: The case of Jordan. International Journal of Business Management, 8 (23), 120-129.

Tam, C. M. Tong, T. K. L., Leung, A. W. T and Chiu, G. W. C. (2002). Site layout planning using non-structural fuzzy decision support system. Journal of Construction, Engineering and Management, 128(3), 220-231. 
Tam, C.M., Zeng, S. X. and Deng, Z. M., (2004). Identifying elements of poor construction safety management in China. Safety Science, 42, 569-586.

Toor, S. and Ogunlana, S. (2008). Problems causing delays in major construction projects in Thailand. Construction Management and Economics, 26(4), 395-408.

Trigunarsyah, B. (2004). A review of current practice in constructability improvement: Case studies on construction projects in Indonesia. Construction Management and Economics, 22 (6), 567-580.

Tumi, S., Omran, A. and Pakir, A. (2009). "Causes of delay in construction industry in Libya." The International Conference on Economics and Administration, Faculty of Administration and Business, University of Bucharest, Romania ICEA - FAA Bucharest, 14-15 ${ }^{\text {th }}$ November 2009.

Walker, D. H. T. and Shen, Y. J. (2002). Project understanding, planning, flexibility of management action and construction time performance: two Australian case studies, Construction Management and Economics, 20(1), 31-44.

Wiguna, I. P. A, and Scott, S., (2005). "Analysing the risks affecting construction delay and cost overruns in Indonesia building projects." $3^{\text {rd }}$ International Conference on Innovation in Architecture, Engineering and Construction, 3, Rotterdam. 841-849.

Winter, J. and Johnson, P. (2000). Resolving complex delay claims. A report on a meeting of the UK Society of Construction Law, at the National Liberal Club, Whitehall Place, London.

Wong, F. W. H., Lam, P. T. I., Chan, A. P. C., and Chan, E. H. W. (2006). A review of buildability performance in Hong Kong and strategies for improvement. Surveying and Built Environment, 17(2): 37-48.

Wong, K. and Vimonsatit, V. (2012). A study of the factors affecting construction time in Western Australia. Scientific Research and Essays, 7 (4), 3390-3398.

Zack, J. G, (1997). Claims prevention: Offence verses Defence. Journal of Cost Engineering, 39(7), 23-28 